Greg Taylor

Knighthoods and the Order of Australia

Australian Bar Review, 2020; 49(2):323-356

\title{
(C) LexisNexis
}

Originally published at:

https://advance.lexis.com/api/permalink/67b2d078-2ef4-4129-9bab-

769338b75b36/?context=1201008\&federationidp=TWWWFB52415

\section{PERMISSIONS}

https://www.lexisnexis.com.au/en/products-and-services/lexisnexis-journals/open-access-repositories-andcontent-sharing

Open Access Repositories

The final refereed manuscript may be uploaded to SSRN, the contributors' personal or university website or other open access repositories. The final publisher version including any editing, typesetting or LexisNexis pdf pages may not be uploaded.

Contributors must note the journal in which the work is published and provide the full publication citation. After 24 months from the date of publication, the final published version, including any editing, typesetting or LexisNexis pdf pages, may be made available on open access repositories including the contributors' personal websites and university websites.

In no case may the published article or final accepted manuscript be uploaded to a commercial publisher's website.

Content Sharing via Social Media

LexisNexis encourages authors to promote their work responsibly.

Authors may share abstracts only to social media platforms. They must include the journal title and the full citation.

Authors may tag LexisNexis so we can help promote your work via our network, when possible.

\section{December 2020}




\title{
KNIGHTHOODS AND THE ORDER OF AUSTRALIA
}

\section{Greg Taylor}

\begin{abstract}
This article considers the legal basis and functioning of the Order of Australia in general, with special reference to the innovations under the prime ministership of Tony Abbott : his two schemes for again awarding Knighthoods in the Order, the first of which bypassed the Council of the Order, as well as his decision to award a Knighthood to Prince Philip. The separate roles of the Council, the Governor-General and The Queen are outlined. International comparisons with Canada and New Zealand are made and case law on honours considered. Other questions not examined by scholars to date include whether failure to confer, or the deprivation of an award in the Order can be reviewed in administrative law. The article concludes by asking what reforms could be made to place the Order on a firmer legal basis, avoid any further embarrassing adventurism and further reinforce the Order's independence from politicians.
\end{abstract}

\footnotetext{
* Fellow of the Royal Historical Society. Professor of Law, University of Adelaide; Honorary Professor of Law, Marburg University, Germany; Honorary Professor, R.M.I.T. University, Melbourne. The author would like to thank $\mathrm{Dr}$ Yee-Fui Ng for providing useful references during research for this article and Dr Christopher McCreery M.V.O. for helpfully providing information about the Order of Canada and general comments on a draft. Thanks are also due to the Honours and Symbols Section of the Department of Prime Minister and Cabinet for answering e-mail enquiries. The usual caveat applies.
} 


\section{Introduction}

The reintroduction of Australian Knighthoods ${ }^{1}$ seemed, at the time (March 2014), to be hard to top in terms of unforeseeability, ${ }^{2}$ not to say eccentricity - until, to the astonishment of a whole nation, one was conferred upon a defenceless Prince Philip on Australia Day 2015. Sufficient time has probably now elapsed since these incidents for a dispassionate examination of the legal aspects of them by a scholar who is not wholly unsympathetic to the ideas behind the reintroduction of a titular distinction in the Order of Australia. It hardly needs to be said that the salesmanship of this idea left a good deal to be desired - indeed, perhaps only computers are capable of comparable incompetence ${ }^{3}-$ but that is not our concern here. Rather, a few hours' research on this topic reveals the quite remarkable fact that, aside from the occasional mention in case law, no consideration of the legal basis of the Order of Australia or of the opportunities to improve its legal underpinnings has ever been published. This article will commence therefore by filling that gap.

\footnotetext{
${ }^{1}$ In order to avoid tedious repetition, in this article Damehoods are taken to be included within this term.

${ }^{2}$ Thus, for example, a scholar of the Australian honours system, writing in the previous year, did not see it coming, despite the foreseeable election of the Abbott government in that year : Fox, "'A Pernicious System of Caste and Privilege' : Egalitarianism and Official Honours in Australia, New Zealand and Canada" (2013) 10:2 History Australia 202.

${ }^{3}$ According to Greg Sheridan, "Loyal to a Fault : Why Philip was Knighted" in "The Australian", 16 September 2015 , p. 1 - writing only a couple of days after Mr Abbott lost the prime ministership - the decision to confer a Knighthood upon Prince Philip (rather than the initial decision to reintroduce Knighthoods in the first place) was 'Tony Abbott's worst mistake as Prime Minister' and had 'cruelled the morale of the Liberal Party'. That writer goes on to state that The Queen herself had asked for this honour to be conferred upon her husband, a claim which has never been denied and is generally thought plausible (although not by Patrick, Credlin \& Co. : How the Abbott Government Destroyed Itself (Black, Carlton 2016), p. 115) - and cf. also what Dr Christopher McCreery M.V.O. says about a comparable proposal at fn 94 below.

John Wanna, "Political Chronicles" (2015) 61 Aust Jo Pol \& Hist 618, 619 rightly sees this incident as the 'final straw' among numerous instances where Mr Abbott had made decisions without sufficient consultation with his colleagues. It is also noticeable that the issue of "Political Chronicles" a year earlier, for the period when Knighthoods were originally restored ((2014) 60 Aust Jo Pol \& Hist 621), does not even mention the topic. On the mild public reaction to the resuscitation of Knighthoods as such (2014) compared to the Prince Philip decision (2015), see also Patrick, supra, pp. 106-116.
} 


\section{The legal basis of the Order of Australia}

\section{a. The Royal prerogative}

Traditionally the source of power to make awards of honours is found in the Royal prerogative. ${ }^{4}$ To some extent the question of the legal source of this power may seem superfluous, given that the conferral of an award can be made by anyone without the need for an express power to do so. For example, a national daily newspaper in this country annually anoints a person of its choice as "Australian of the year" without any mandate from anyone to do so. Numerous other awards made by private or semi-private organisations exist. Universities confer honorary doctorates and declare staff members to be champion teachers of the year and so on. Learned societies declare that their fellows are entitled to use post-nominals. At the risk of ridicule, anyone could create their own order of knighthood along those of the Papacy, the Most Venerable Order of the Hospital of Saint John of Jerusalem $^{5}$ and its Continental branches and the orders of various deposed Royal families. ${ }^{6}$ There are of course also various foreign awards of legitimate states. ${ }^{7}$ It could be argued that the Crown, by making awards, is simply doing what any body of persons, or indeed any individual person could do,

\footnotetext{
${ }^{4}$ The point, for obvious reasons, comes up infrequently, but see, for example, Council of Civil Service Unions v. Minister for the Civil Service [1985] AC 374, 418; McKeown/Thomson, "Sources of Law and the U.K. Honours System" [2012] SLT 81, 81.

${ }^{5}$ For the recent notice in the official gazette of this Order's conferral of the title of Dame of Grace on the Governor of New South Wales, see Commonwealth of Australia Gazette,4 March 2019, C2019G00215. The Order of Australia's founder would not be amused by such indulgences as the commandeering of the official gazette by this Order: Whitlam Q.C., The Truth of the Matter ( $2^{\text {nd }}$ ed., Melbourne U.P. 2006), p. 233.

${ }^{6}$ Robson (ed.), Who's Who in Australia (55 th ed., A.A.P. Directories, Southbank 2018), p. 63, contains a warning about purchased or self-conferred titles, 'an intriguing eccentricity but a distraction for the compilers of Who's Who in Australia. The titles show some ingenuity, for example the "Order of Bountiful Endeavours" with the initials O.B.E.'

In $R$ v. Bartle (2003) 181 FLR 1, one of the convicted accused was Sir Thomas Graham Fry, "Sir" being just another given name. See also Walsh v. Registrar, Supreme Court of Norfolk Island [2018] FCA 1075.

${ }^{7}$ There are Guidelines concerning the Acceptance and Wearing of Foreign Honours and Awards by Australians (approved by Her Majesty The Queen in August 2012), published in the Commonwealth of Australia Gazette, 12 October 2012, no. S159 (C2012G00060). Except for persons employed by the government, the precise legal basis of these guidelines may be questioned, although they have long been issued in the United Kingdom also. Those published in the London Gazette, 22 May 1914, p. 4116 give no other source for their validity besides 'the King's wish'. The first Australian issue of such guidelines was in 1989 : Review of Australian Honours and Awards, A Matter of Honour : the Report of the Review of Australian Honours and Awards (A.G.P.S., Canberra 1995), p. 47.
} 
and thus the power is not a prerogative one. The better view is that powers shared with subjects are not prerogative powers. ${ }^{8}$

Such reasoning would, however, overlook the fact - and I believe this is not circular - that it is only the Crown's awards that claim to be made on behalf of the state, which in this case of course is the Australian state. It is true to say that only the Crown can make awards on behalf of the national community of which we are all members whether we like it or not. Therefore, the Crown's power to make awards has a special nature which is not shared with, for example, a newspaper's legal right to announce distinctions of its own invention.

It is, moreover, right and proper - indeed, it is an aspect of the rule of law - that every action by the state should be referable to some source of power. This principle is also promoted by decisions such as Williams v. Commonwealth (No. 1). ${ }^{9}$ Our enquiry about the Crown's power to make awards and institute orders is therefore not an idle one. The traditional answer referring to the common-law prerogative power is quite a suitable one for another reason : pinning various baubles on to people's clothing and their subsequent adoption of assorted post-nominals or the title "Sir" or "Dame" are harmless - not, indeed, to prime ministers, to whom they can be politically fatal, but in a more strictly legal sense : no-one is threatened with deprivation of life, liberty or property as a result of such actions. Indeed, it is perfectly legal, of course, to leave out the post-nominals or to refuse to refer to a titled person by the title "Sir" or "Dame", and indeed the writer recalls seeing advocacy of such action during the brief second coming of Australian Knighthoods.

However, despite its general inoffensiveness and antiquity this state of the law has been doubted in recent times. The motives for these doubts may be legal nationalism or a desire for textual fidelity, or both, for the suggestion made by French C.J., Crennan, Kiefel and Bell JJ. in Kline v. Official Secretary to the Governor-General ${ }^{10}$ is that ' $[\mathrm{t}]$ he grant of honours, once regarded as part of the prerogative of the Crown, is now encompassed in the executive power conferred by s $61^{\prime}$ of the federal Constitution.

\footnotetext{
${ }^{8}$ See for example Williams v. Commonwealth (No. 1) (2012) 248 CLR 156, 344; Taylor, The Constitution of Victoria (Federation, Leichhardt 2006), p. 101; Tomkins, "The Authority of Entick v. Carrington" in Entick v. Carrington : 250 Years of the Rule of Law (Hart, Oxford 2015), p. 173.

${ }^{9}$ (2012) 248 CLR 156.

${ }^{10}$ (2013) 249 CLR 645, 653. On this case, see Cremean, “Orders of Australia” (2011) 19 Aust Jo Admin Law 7.
} 
While thus enjoying a majority of the High Court of Australia in its favour, this dictum was not necessary to the decision in the case and may therefore be regarded as obiter. The nature of the suggestion is also unclear : at first it could be read as stating that the Crown's prerogative has been superseded wholly or in part by the powers conferred by s 61 . One difficulty with that theory would be knowing which powers, formerly of the prerogative, are 'now encompassed in the executive power conferred by $s 1^{\prime}$. The only way of doing so would be to refer to lists of long-recognised prerogative powers again, rendering this exercise rather pointless. ${ }^{11}$ Thus, if the power to provide honours is now within s 61 , this must be because it was previously a prerogative power. The bottle would have the same contents with only its label changed.

One does not need to believe in the common law as truly the ultimate constitutional foundation to question whether this is necessary or achieves anything much : just as much fidelity to the text can be obtained in other ways. Thus, only a few years earlier in Cadia Holdings v. New South Wales, ${ }^{12}$ Gummow, Hayne, Heydon and Crennan JJ. declared that s 61 'includes the prerogative powers accorded the Crown by the common law' - a preferable position which avoids the objection just raised while achieving just as much fidelity to the text and autochthony. Indeed, French C.J. seems to have refined his position in the direction stated, for we find his Honour in "C.P.C.F." v. Minister for Immigration and Border Protection ${ }^{13}$ stating :

The history of the prerogative powers in the United Kingdom informs consideration of the content of $s 61$, but should not be regarded as determinative. The content of the executive power may be said to extend to the prerogative powers, appropriate to the Commonwealth, accorded to the Crown by the common law. ${ }^{14}$

\footnotetext{
${ }^{11}$ Zines, "The Common Law in Australia : its Nature and Constitutional Significance" (2004) 32 Fed LR 337, 348. For an in-depth discussion of this matter not limited to the context of honours, see Gerangelos, "The Executive Power of the Commonwealth of Australia : Section 61 of the Commonwealth Constitution, 'Nationhood' and the Future of the Prerogative" (2012) 12 Ox U Clth L 97, 105-112.

${ }^{12}$ (2010) 242 CLR 195, 226; and see at 228 [94].

${ }^{13}$ (2015) 255 CLR 514.

${ }^{14}$ At 538. Kiefel J., in dissent, deals inconclusively with this question at 595; at 654, Keane J. assumes that 'prerogative power' is still a subsisting category in Australian law. See also Williams (No. 1), (2012) 248 CLR 156, 185.
} 
One further objection to abandoning the idea of the prerogative exists. An important feature of the prerogative was its vulnerability to displacement by statute. If formerly prerogative powers are now regarded as conferred by s 61 , could they be altered or abolished only by amending the Constitution? Given the various amendments to the statutes of the Order of Australia made during its forty-fiveyear life, would it be "frozen" at some point and if so at which point? Or would only the powers themselves be part of $s 61$ and not the precise manifestation of them in prerogative instruments of various sorts? This, in the end, would probably raise a question of the level of generality at which the prerogative powers had achieved constitutional status. In our field, the sorts of questions that would be raised by a constitutionalised prerogative can be simply illustrated : would s 61 incorporate only some power to create an honours system of any sort, or would the executive's power to confer Knighthoods be included within the power conferred by s 61 and thus beyond Parliament's reach? Can the executive's power to confer Knighthoods be finally abolished only by amending the Constitution?

This is not a theoretical question : one response to the knighting of Prince Philip was a proposal for a private member's Bill preventing the award of further Knighthoods. Its proponent, Dr Andrew Laming M.P. from the Liberal Party, is said in a newspaper report to have received the following advice on it from Professor George Williams A.O. :

It avoids constitutional problems because it does not seek to rewrite the executive instruments, notably the Letters Patent, but merely sets down in legislation a standard indicating that it is unlawful for future appointments of this kind [i.e. Knighthoods] to be made by the executive.

It is well accepted that Parliament may regulate the exercise of executive power of this kind. ${ }^{15}$

Indeed it is, and that is because a common-law prerogative power is involved, not a power conferred directly by s 61 . In fact it is open to Parliament, should it so desire, to go much further by repealing the Letters Patent entirely ${ }^{16}$ and providing that no honours system should ever be created again - as

\footnotetext{
${ }^{15}$ Rosie Lewis, “M.P. says Knights Kill Bill 'Fundamentally Flawed’”, “The Australian”, 6 February 2015, p. 4.

${ }^{16}$ Cf. Constitution Act 1902 (N.S.W.) s 9F.
} 
Parliament cannot bind itself, this would not prevent any future statutory resuscitation, but would remove the prerogative power until the statute was repealed. Alternatively, Parliament could provide its own legislation for an honours system coupled with a provision that the Royal prerogative to create honours should not be exercisable in future. As long as the prerogative powers continue and are merely recognised, but not completely replaced by s 61 there is no possible constitutional objection to any such course. Indeed, it may be preferable to enact a statute - a question to which I shall return. At any rate, Parliament retains the final say, if it chooses to have it, over a prerogative power to confer honours that fits within s 61 but is antecedent to it.

\section{b. Federal aspects of the prerogative}

What I have written so far assumes that honours do fall within federal legislative and executive power. This would seem to be a fairly uncontroversial position.

That does not imply that the States also do not have such power. Indeed, the better view is that they do, merely leaving it largely unexercised. ${ }^{17}$ It seems intuitively obvious, however, that the federal level of government must also partake of the honours prerogative. According to former Justice Ken

\footnotetext{
${ }^{17}$ Taylor, above $\mathrm{n} 8$ at 107-109. It is therefore unnecessary to consider quasi-theological questions about the (in)divisibility of the Crown of Australia in this field : they have even less practical significance than usual. Furthermore, the example of Canada shows that federal and local honours could happily co-exist. In the 1970 s a federal veto over a proposed State honours system seems to have been successfully implemented on the ground that 'Royal warrants in such matters are issued on the recommendations of Prime Ministers alone' (Whitlam Q.C., The Whitlam Government 1972 - 1975 (Viking, Ringwood 1985), p. 140), but any comparable modern federal advice to The Queen to frustrate the creation of a State honours system would be neatly parried by a reminder that Her Majesty's powers relating to the States now cannot usually be exercised by her anyway (s 7 (2) and (4) of the Australia Act 1986 (Imp. \& Clth)).

The Review of Australian Honours and Awards, above $n 6$ at 219, refers mysteriously to interest in some States in creating their own system of awards. Evidently nothing came of these proposals, but that was not for want of any legal power.

Below it will be proposed that the Order of Australia should be established by federal Act of Parliament instead of prerogative instrument. This, if it were done, might raise the issue whether State honours could be ruled out under such legislation using s 109 of the Constitution (which would appear inapplicable to legislation of the Commonwealth that is not parliamentary but made under the prerogative). Little space should be devoted to this doubly hypothetical possibility, but my view in brief is that this could not be done : there could be no direct inconsistency, and as far as covering the field is concerned federal laws would be awards for federal purposes made by the federal polity, while State awards would be awards for State purposes made by the State. Nor could a naked prohibition of State awards be enacted federally for the reasons explored by Mr N. Dour and me in "Manufactured Inconsistency" (2013) 39 Mon ULR 131. However, much more time and effort would be needed for a proper examination of this possibility if it ever became a reality.
} 
Hayne A.C., the power to create national awards is a necessary consequence of the Commonwealth's establishment as a polity and thus able to be conceded to the federal executive as no undue enhancement of its powers ${ }^{18}$ - although it is noticeable that his former Honour both deprecates argument by assertion in this field and here provides an example of it, for he neither provides a criterion of necessity nor considers, despite his own strictures, why it is necessary for the executive rather than Parliament to possess the power to create awards (not confer individual awards, which could indeed hardly be done by the legislature).

As far as federal legislative power is concerned, the nature of the prerogative as always vulnerable to parliamentary adjustment or extinction means that, if a prerogative power is exercisable by the federal executive, it can be regulated or abolished also by the Federal Parliament. This is not reasoning backwards from a desired conclusion : it is a matter of basic constitutional principle - no action of the executive can possibly fall outside the purview of Parliament, and prerogative powers exist only at its sufferance. Furthermore, if it is desired to locate one there is an obvious home for the honours system among federal powers : the nationhood power. The honours system is one of 'the symbols of nationhood [such as] a flag or anthem'. ${ }^{19}$ Virtually every country in the world has an honours system of some sort. ${ }^{20}$ Its absence from the Australian scene would be odd indeed - it would be even odder to find not merely a national honours system absent, but also that one could not possibly be created, even by federal Parliament.

Nevertheless Professor Anne Twomey, among others, has cogently criticised the looseness of the reasoning behind declarations that this or that federal function can be justified under the nationhood power and adds wittily, '[t]here is no reason to fear that we would be flagless or anthemless in the absence of a nationhood power'. ${ }^{21}$ The present author, who would incidentally welcome rather than fear the disappearance of the present National Anthem's dismal doggerel, has also always doubted the need for the nationhood power and the justification for inserting another unwritten power into

\footnotetext{
18 “Executive Power" (2017) 28 PLR 236, 246f. See also "C.P.C.F.", (2015) 255 CLR 514, 565.

${ }^{19}$ Davis v. Commonwealth (1988) 166 CLR 79, 111.

${ }^{20}$ Apparently Ireland is the only or the major exception, and if so it may well be the exception that proves the rule, for according to their Lordships in Re Earl of Antrim's Petition [1967] 1 AC 691, 716, 719 Ireland has simply ceased to exist (and therefore can no longer be represented in the House of Lords), making its lack of an honours system readily explicable. Perhaps another exception is Sweden, which has not abolished its honours system but has awarded honours for some decades only to foreigners and members of its royal family. 21 "Pushing the Boundaries of Executive Power - Pape, the Prerogative and Nationhood Powers" (2010) 34 MULR 313, 336.
} 
s 51's extremely long and thorough list, clearly intended to be complete, of federal powers. If there is anything that can be justified as an example of the nationhood power, it is an honours system, but it is also sufficient simply to say that as there is a prerogative executive power to create an honours system there must also be a parliamentary power to regulate and even to abolish it. If it is desired to find a home for this parliamentary power on the list in s 51 rather than using the nationhood power, it may be recalled that it is certainly an incident of the prerogative, and thus perhaps a 'matter[] incidental' to it within the meaning of s 51 (xxxix), that it is always amenable to parliamentary control.

\section{c. The Letters Patent and other formal documents}

As a valid exercise of prerogative power by the Crown, Letters Patent create the Order of Australia and provide a constitution for it. It is interesting to observe at this point that the initial and subsequent amending Letters Patent have always been issued by Her Majesty The Queen, not by the GovernorGeneral. They are countersigned by the Prime Minister, thus indicating their federal source.

A booklet containing the Letters Patent and updated constitution of the Order as well as the ordinances (of which more anon) is published on the Governor-General's web site. ${ }^{22}$ The Order's constitution is also published with all amendments incorporated by the federal Office of Parliamentary Counsel using the Federal Register of Legislation and the same format that is used for federal Acts of Parliament; ${ }^{23}$ the ordinances may be found there as well. Letters Patent are primary (i.e. not delegated) legislative instruments that are not to be found among the Acts of Parliament because they are issued by the executive pursuant to its remnant of prerogative power. Instead each amendment to the Order's constitution is published in the Commonwealth of Australia Gazette and also, under the otherwise barely used title "other - prerogative instruments", on the on-line Federal Register of Legislation. ${ }^{24}$

\footnotetext{
22 The booklet also includes a picture of The Queen, a message from the Governor-General, pictures of the Order's insignia, a brief introduction and a list of contact persons. At the time of writing it could be found at https://www.gg.gov.au/sites/default/files/2019-09/PRINT\%20FINAL\%20Order\%20of\%20Australia\%20Booklet\%2000SGG.PDF.

${ }^{23}$ At the time of writing the latest version was compilation no. 16, Register i.d. C2018Q00016 on the Federal Register of Legislation.

${ }^{24}$ Presumably the legal basis for this registration is the catch-all ability to register anything useful in ss $15 \mathrm{G}$ (5) \& $15 \mathrm{H}$ (2) of the Legislation Act 2003 (Clth). As solely a prerogative power is involved here, instruments relating to the Order of Australia are neither legislative nor notifiable instruments under that Act : see in particular
} 
As the Letters Patent and constitution are thus freely available, this is not a general history of the Order of Australia ${ }^{25}$ and many of its most important features will be considered in detail below, I shall confine myself to an overview of the structure of the Order's legal documents. The Order's constitution is set out in the Schedule to the Letters Patent, dated 14 February 1975 and counter-signed by one E.G. Whitlam Q.C. as Prime Minister. Her Majesty used, of course, the new Royal style and titles conferred upon her under the Royal Style and Titles Act 1973 (Clth $)^{26}$ - making it clear that she was acting as Queen of Australia. The Letters Patent recited that 'it is desirable that there be established an Australian society of honour for the purpose of according recognition to Australian citizens and other persons for achievement or for meritorious service' and thereupon established 'a society of honour to be known as the "Order of Australia"'. ${ }^{27}$ The constitution of the Order was annexed as a Schedule to the Letters Patent. While the body of the Letters Patent has never been amended, the Schedule containing the constitution has been amended sixteen times since 1975. Such amendments are also made by Letters Patent issued by Her Majesty. The body of the Letters Patent of 1975 contain no numbered clauses; the constitution in the Schedule contains numbered items up to thirty-one. As with a statute, these are designated as "sections" within the constitution itself and they are divided into what are also called by the statutory terms of sub-sections, paragraphs and sub-paragraphs.

At the same time as the Order of Australia was created, Letters Patent were also issued reciting that 'it is desirable that there be instituted certain Australian decorations for the purpose of according recognition to Australian citizens and other persons who perform acts of bravery' and creating the Cross of Valour, the Star of Courage, the Bravery Medal and the Commendation for Brave Conduct. ${ }^{28}$ In contrast to the Order of Australia, no formal society of honour was created by these Letters Patent. Since then various other decorations and awards have been created under the prerogative power by Royal Letters Patent, such as the Public Service Medal ${ }^{29}$ and the Distinguished Service Cross, Medal

para. (b) of the definition of "power delegated by the Parliament" in s 4, which embraces only those prerogative instruments that are also authorised by an Act of Parliament.

${ }^{25}$ There is no full-scale history of the Order. One useful substitute is Hazell, "The Australian Honours System : An Overview" in Jackson (ed.), Honouring Commonwealth Citizens : Proceedings of the First Conference on Commonwealth Honours and Awards (Ontario Ministry of Citizenship and Immigration, Toronto 2007), ch. 2.

${ }^{26}$ The Act gave Parliament's assent to the new style and titles, which were then adopted by Royal proclamation : Australian Government Gazette, 19 October 1973, p. 5.

${ }^{27}$ Australian Government Gazette, 17 February 1975, no. S28 (C2010000031).

${ }^{28}$ Australian Government Gazette, 17 February 1975, no. S28 (C2010Q00056).

${ }^{29}$ Commonwealth of Australia Gazette, 28 November 1989, no. S369 (C2010Q00075). 
and commendation. ${ }^{30}$ A special case was constituted by the Victoria Cross for Australia, ${ }^{31}$ continuing a well-known earlier distinction of the highest rank. None of these awards will be considered further here.

Subordinate legislation, known as ordinances, can also be made under s 30 of the Order of Australia's constitution. That section, drafted very much on the model of a statutory power to make regulations, gives power to the Governor-General to make ordinances for general purposes and for five named purposes : 'the government of the order', its insignia, the designations of the members, investitures and terminations or cancellations of awards. ${ }^{32}$ At the time of writing ordinances existed on all these topics. Good examples germane to the present topic are paragraphs (a) and (b) of regulation 3 of the Designations and Insignia Ordinance ${ }^{33}$ - again the items are designated in accordance with legislative conventions, here those applicable to regulations. Those paragraphs provide that a Knight or Dame of the Order may use the title "Sir" or "Dame" and the post-nominals "A.K." or "A.D." as well as wearing the prescribed insignia. These are in turn prescribed under reg. 7 of the Insignia Ordinance. ${ }^{34}$ The same two ordinances also prescribe designations and insignia for the other ranks of the Order.

Recently a further section, 30A, permitting ordinances to be made has been added to the Order's constitution; ${ }^{35}$ it explicitly requires, unlike $s 30,{ }^{36}$ the Prime Minister's recommendation. The sole topic of ordinances made under s $30 \mathrm{~A}$ is the quotas - the yearly number of appointments at each level in the general division (not the military division) of the Order, previously dealt with in the constitution itself. According to the Governor-General's annual report,

The changes ensure an ongoing efficient mechanism that enables the quotas to be varied in response to changing circumstances in Australia. The Ordinance subsequently made on 19

\footnotetext{
${ }^{30}$ Commonwealth of Australia Gazette, 4 February 1991, no. S25 (C2010Q00026).

${ }^{31}$ Commonwealth of Australia Gazette, 4 February 1991, no. S25 (C2010Q00025).

${ }^{32}$ As s 25 (2) (c) \& (d) of the Order's constitution makes clear, this is simply a difference in wording : all awards except that of the Medal of the Order are terminated; the award of the Medal is cancelled.

${ }^{33}$ Federal Register of Legislation, C2010Q00045.

${ }^{34}$ Federal Register of Legislation, C2010Q00080.

${ }^{35}$ Commonwealth of Australia Gazette, 24 April 2018, C2018G00297.

${ }^{36}$ Again, if it were an Act in question, s 16A of the Acts Interpretation Act 1901 (Clth) would imply a requirement that the Governor-General must act with the advice of the Executive Council under s 30, but that section does not apply to prerogative instruments.
} 
April $2018^{[37]}$ maintained the current quotas, with the exception of the Member of the Order of Australia (A.M.), which was increased by 25 in a calendar year. (The current quota is now 365.) There remains no annual quota on the Medal (O.A.M.). ${ }^{38}$

Enhancing flexibility is the usual reason why a matter might be moved from the primary legislation (here issuing from Buckingham Palace, usually made by Parliament) to delegated legislation (here, as is often so, issued from Yarralumla).

Honours policy is, as we shall see, quite properly a matter for the Prime Minister, Cabinet and the Department of the Prime Minister and Cabinet (which has an Honours and Symbols Section). However, the Department has informed the author that it does not provide advice to the Governor-General's office on the ordinances to be made under s 30 , taking the view that the administration of the order in these respects is a matter for that office. Only on the topic dealt with in $\mathrm{s} 30 \mathrm{~A}$ is such advice provided. ${ }^{39}$ Of course, The Queen always acts on governmental advice when making amendments to the Order's constitution. Thus the effect of the new s 30A, in moving the setting of quotas from the Order's constitution to ordinances requiring prime ministerial advice, is that governmental advice on that topic will henceforth be provided to the Governor-General not The Queen. Evidently it was thought that the government should retain its accustomed role in determining the quotas and the matter was not confided to the Governor-General alone.

\footnotetext{
${ }^{37}$ Constitution of the Order of Australia (Number of Appointments in the General Division) Ordinance 2018 (Commonwealth of Australia Gazette, 27 April 2018, C2018G00302), which was countersigned by the Prime Minister given the requirement for the Prime Minister's recommendation in s $30 \mathrm{~A}$. After this article was accepted for publication, however, the quotas were changed by the Constitution of the Order of Australia (Number of Appointments in the General Division) Ordinance 2019 (Commonwealth of Australia Gazette, 3 April 2019, C2019G00308) without any indication of the Prime Minister's approval of the Ordinance.

${ }^{38}$ Office of the Official Secretary to the Governor-General, Annual Report 2017-18 (The Office, Canberra 2018), p. 40. Letters Patent had last changed the quotas two years earlier, in 2016 : Commonwealth of Australia Gazette, 11 October 2016, C2016G01347.

${ }^{39}$ Unsigned e-mail from the source stated to the author, 15 February 2019.
} 


\section{d. Her Majesty or His Excellency?}

Earlier, the somewhat out-of-the-way topic of a State honours system was briefly mentioned. Should such a thing ever be created, under s 7 (2) and (4) of the Australia Act 1986 (Imp. \& Clth) it could be done only by the Governor unless The Queen were personally present in the State and able to exercise the Royal powers in person. Otherwise all State prerogative powers, like all Royal powers relating to a State except the appointment of a Governor, must be exercised by the Governor. ${ }^{40}$

For some reason care has been taken to adopt the opposite approach at federal level. As we have just seen, while the subordinate rules of the Order, the ordinances, are made by the Governor-General, and one particular topic - the quotas - has just been removed from the Palace's and added to the Governor-General's own authority (with prime ministerial recommendation), the Order was created by Letters Patent issued by The Queen and all amendments to its constitution since have proceeded from the same source. Is the reason some sort of legal impediment to the Governor-General's taking action alone, or is it merely a question of tradition and perceived prestige along with the fact that The Queen is also Sovereign of the Order? (The position within the Order held by the Governor-General is Chancellor and Principal Knight or Companion. ${ }^{41}$ It is also worth noting that appointments to the Order are made, according to s 9 of the Order's constitution, 'with the approval of the Sovereign, by Instrument signed by the Governor-General'. This wording has not changed since 1975 but the Keating government ended the practice by which proposed awards were presented to Her Majesty for her approval; now she merely receives information about awards after the fact. $)^{42}$

\footnotetext{
${ }^{40}$ Despite this, a delegation of power to permit the retention of the title "Honourable" to State Governors is recorded by Twomey, Constitution of New South Wales (Federation, Leichhardt 2004), p. 153. This was clearly unnecessary, but it may have been done merely out of caution or because it was thought that titles conferred by Her Majesty should continue to be under her personal supervision. See further below, fn 151 .

${ }^{41}$ Section $2(1),(1 \mathrm{~A}),(1 \mathrm{~B})$ of its constitution.

${ }^{42}$ Smith, "The Australian Honours System in the Beginning" in Proceedings of the Twenty-Sixth Conference of the Samuel Griffith Society Mercure Melbourne, August 2014 : Upholding the Australian Constitution Volume Twenty-Six (The Society, Melbourne 2016), p. 76; Review of Australian Honours and Awards, above $n 6$ at 24, 300 (exception for the Victoria Cross, which is not part of the Order). It is also noticeable that announcements of awards no longer refer to Her Majesty The Queen's gracious approval of the awards, but merely begin : 'The Governor-General is pleased to announce the following appointments and awards'. The changes on this front are traced by Martin, "Perspectives on the Honours of Australia" in Jackson (ed.), above n 25 at 57.
} 
It is doubtless true that, in colonial times, Vice-Regal officers could not have exercised the prerogative power to create honours. Even in this field, however, in Queen Victoria's diamond jubilee year the Privy Council affirmed, in obiter dicta, the capacity of the Crown, in combination with a colonial legislature (i.e. through Act of a colonial legislature), to create honours : 'even in the case of titles of honour', their Lordships stated, 'it does not appear to be doubtful that the Sovereign may, with the assistance of an Act of the Legislature, exercise the prerogative in a manner which would but for its provisions be unconstitutional'. ${ }^{43}$ While they went on to give an example involving the Westminster Parliament, namely the creation of life peerages for the law lords by statute, the remainder of the judgment indicates that they also thought colonial legislatures capable of working similar constitutional wonders. Nevertheless, without the backing of a local Act of Parliament it is almost certainly correct to say that a nineteenth-century colonial Governor without an express delegation authorising him to do so could not have created a local honours system. ${ }^{44}$ It is even more certain that such a Governor would have faced a severe reprimand from the Colonial Office and possible recall.

Nowadays, however, as Barwick C.J. rightly pointed out in the Seas and Submerged Lands Case, ${ }^{45}$ we have, thanks to s 61 of the federal Constitution, a Governor-General who is 'in truth a Viceroy' capable of exercising every Royal power appertaining to the federal Australian government. This must include the prerogative of honours, and H.E. Renfree C.B.E. ${ }^{46}$ is therefore correct to say that the retention of this power by Buckingham Palace 'is a matter of comity rather than of strict law, and there is no reason why honours should not be granted by the Governor-General as The Queen's representative on the advice of Australian ministers and without even consulting the Sovereign'. That must apply both to individual awards and to the setting up of the entire system, and the only thing to add is that the involvement of The Queen is not merely a matter of 'comity' but would also, in the eyes of some at least, elevate the prestige of the Order. There seems no good reason to do without that effect apart from convenience.

\footnotetext{
${ }^{43}$ Attorney-General (Canada) v. Attorney-General (Ontario) [1898] AC 247, 252.

${ }^{44}$ Todd, Parliamentary Government in the British Colonies ( ${ }^{\text {nd }}$ ed., Longmans Green, London 1894), p. 313. Further statements to the same or a similar effect are collected and criticised in Evatt, The Royal Prerogative (Law Book, North Ryde [1924] 1987), pp. 115f. For an interesting exchange of views on this question, see Moore, George Higinbotham and Eureka : The Struggle for Democracy in Colonial Victoria (Australian Scholarly Publishing, North Melbourne 2018), p. 277.

45 (1975) 135 CLR 337, 373.

${ }^{46}$ The Executive Power of the Commonwealth of Australia (Legal Books, Sydney 1984), p. 511.
} 
If it ever were desired to do without involvement from London, caution would nevertheless suggest a delegation of the power to the Governor-General to amend the Letters Patent, or some amendment to them having the same effect, in order to prevent any argument that the stream has attempted to rise above its source. Such action was recommended by the Review of Australian Honours and Awards in 1995, except in relation to new awards which, the committee thought, should still be approved by the Sovereign as fount of honour. ${ }^{47}$ It may also be noted that the Order's constitution has contained since 1975 , in s 10 , the following provision :

10. Nothing in this Constitution limits the right of the Governor-General to exercise all powers and authorities of the Sovereign in respect of the Order.

This is somewhat reminiscent of s 51 (xxxviii) of the federal Constitution and supports the approval of all honours by the Governor-General rather than The Queen ${ }^{48}$ which the Keating government introduced. ${ }^{49}$ But as it stands it does not allow the Governor-General to amend the constitution of the Order : it is not The Queen as Sovereign of the Order who amends its constitution, but The Queen qua Queen.

Although s 61 of the Australian Constitution does not of course apply in Canada, ${ }^{50}$ the constitution of the Order of Canada is amended from Rideau Hall (Government House) in Ottawa, not Buckingham Palace. ${ }^{51}$ Yet it is curious to find that, in a related field, it was still thought necessary to delegate powers to the Canadian Governor-General : when the Canadian Heraldic Authority was to be set up, the initial step was for The Queen to delegate to the Governor-General of Canada 'all powers and authorities lawfully belonging to Us as Queen of Canada in respect of the granting of armorial bearings

\footnotetext{
${ }^{47}$ Above $\mathrm{n} 6$ at 301.

48 Hazell, above $\mathrm{n} 25$ at 47.

49 See above, $\mathrm{n} 42$.

50 In Canada, there is a general delegation in cl. II of the Letters Patent published in Canada Gazette, Part I, 1 October 1947, p. 3104. Curiously it is followed by a number of specific delegations of powers such as the power to dissolve Parliament and grant pardons. Perhaps this is what caused the doubts about the heraldry powers.

${ }^{51}$ See, for example, Canada Gazette, Part I, 19 July 1997, p. 2087. The initial establishment of the Order was by Her Majesty's own Letters Patent, which indeed recited that 'the establishment of the Order of Canada is properly of concern to Her Majesty as Queen of Canada and should be made only with Her Majesty's personal approval' (Canada Gazette, Part 1, 29 April 1967, p. 1249). However, amendments from very early on have been made by the Governor-General.
} 
in Canada'. ${ }^{52}$ However, this was probably unnecessary, and done solely for symbolic reasons and to avoid even the smallest grain of doubt based on the long-standing practice of deferring to the U.K. authorities in this field. ${ }^{53}$ In New Zealand also, the Royal prerogative of honours is exercised from Buckingham Palace for symbolic reasons and, in relation to the actual grant of honours, because that is what the relevant statutes of the orders concerned require. ${ }^{54}$

${ }^{52}$ Canada Gazette, Part I, 11 June 1988, pp. $2227 f$.

${ }^{53}$ Agnew of Lochnaw, "The Conflict of Heraldic Laws" [1988] Juridical Review 61, 67 (different prerogative powers involved in various Realms); Cox, "The Office of the Chief Herald of Ireland and Continuity of Legal Authority" (2007) 29 Dublin ULR 84, 96; Cox, "The Royal Prerogative in the Realms" (2007) 33 Clth Law Bull 611, 629; Lordon Q.C., Crown Law (Butterworths, Toronto 1991), pp. 101 f.

${ }^{54}$ Cox, "The Dichotomy of Legal Theory and Political Reality : the Honours Prerogative and Imperial Unity" (1999) 14 Aust Jo Law \& Soc 15, 17, 22, 41.

On heraldry powers in Australia, see Commonwealth Parliamentary Debates, House of Representatives, 7 February 2018, p. 700, where the Prime Minister states, on advice of his Department, as follows :

The practice of the College of Arms in England granting armorial bearings to Australians is well established as one way Australians can obtain heraldic insignia if they wish to do so. There is nothing preventing any person or organisation from commissioning a local artist, graphics studio or heraldry specialist to design and produce a coat of arms or identifying symbol. Those arms would have the same standing and authority in Australia as arms prepared by the College of Arms in England.

This answer is a masterpiece of ambiguity, but implies that the College of Arms' powers in this country are rated no higher than those of any private body or person in Australia. It should be noted, however, that reg. 16 of the Insignia Ordinance of the Order of Australia deals with the accoutrements of grants of arms by Garter King of Arms to members of the Order.

At https://www.college-of-arms.gov.uk, the College itself claims to be 'the official heraldic authority for England, Wales, Northern Ireland and much of the Commonwealth including Australia and New Zealand'. The Australian Heraldry Society, which would like to see a local heraldic authority on the Canadian model, rejects this claim : http://www.heraldryaustralia.org/heraldic-authority. 


\section{Knighthoods in the Order of Australia - the Abbott system}

\section{a. The Council of the Order of Australia}

Like much machinery of the Order of Australia, the Council for the Order of Australia was modelled upon the Advisory Council for the Order of Canada; the Order's progenitor, the Hon. E.G. Whitlam A.C. Q.C., described its role as follows : ${ }^{55}$

The most important difference between the Order of Australia and the Imperial honours is the method of selecting the recipients. Imperial awards are made on the recommendations of politicians while the awards in the Order of Australia are made by the Council of the Order. Nominations may be made to the Council by any person or organisation including any government or party or politician. A politician can sponsor an award in the Order of Australia but no politician can decide that it will be given. All representations are generated through the Council and no award is made unless it is considered and recommended by the Council. ${ }^{56}$

Some qualifications and additions are necessary to these broadly correct statements : under ss 9 and 10 of the Order's constitution awards are actually made, as we have seen, by the Governor-General, with the Sovereign's approval, now dispensed with; the role of the Council is not to make awards, but to consider recommendations to the Governor-General following nominations of citizens for awards and permanent residents for honorary awards. ${ }^{57}$ Accordingly, and secondly, other persons are appointed as honorary members to the Order without any recommendation of the Council - visiting or visited foreign dignitaries, for example, as honorary members. ${ }^{58}$ It is of course a long-standing international practice for such awards to be made during state and official visits, and the present Governor-

\footnotetext{
55 On the historical links and differences between the two, see, for example, McCreery, The Order of Canada : Genesis of an Honours System ( $2^{\text {nd }}$ ed., U. of Toronto Press, 2018), pp. 207f; Hazell, above n 25 at $40 f ;$ McCreery, "Canada's National Honours : An Assessment" in Jackson (ed.), above n 25 at 105; Whitlam Q.C., above $n$ 17 at $141 f$.

${ }^{56}$ Whitlam Q.C., above $\mathrm{n} 17$ at 143.

${ }^{57}$ Constitution of the Order, s 5 (a), (b). See further below, fn 77.

${ }^{58}$ Of course the founder of the Order, as he might well be styled, was aware of these refinements and indeed refers to this one slightly after the quotation just reproduced, with special reference to the case of Joern Utzon A.C.
} 
General holds several such awards from foreign countries. There is, thirdly, also a different process for all awards in the military division of the Order. Finally, although there was no formal system for doing so it was possible to nominate oneself or others for Imperial honours informally by contacting influential people or those thought to be influential.

With these qualifications, the statements quoted are accurate - and the principal point is that the nomination process for the Order of Australia, being independent of political jobbery, favouritism and whim and based rather on an assessment of merit, is far superior to that for the former system; nominating proposed recipients involves doing nihil obscure [...], ut studia cupiditatesque honorum atque ambitiones ex omnibus civitatibus tolleret, quae res evertendae rei publicae solent esse. ${ }^{59}$ Indeed, in 2006 Malcolm Hazell C.V.O., ${ }^{60}$ Official Secretary to the Governor-General and Secretary of the Order, observed that '[i]n keeping with the apolitical nature of the awards system, by convention the Prime Minister and Premiers of State governments do not put forward nominations nor influence the process'. ${ }^{61}$ (At least, that is the theory : heads of government can easily arrange for others to put forward names and then lobby Council members for them, and one former member of the Council reported in the mid-'90s lobbying by prime ministers and vetting of lists by premiers, presumably through their respective States' representatives on the Council. ${ }^{62}$ Let us hope that such behaviour is a thing of the past.)

Sir David Smith K.C.V.O., A.O. reports a previous occasion on which this system needed to be defended from the actions of the government. In 1984 Cabinet, without consultation with or even notice to the Governor-General, approved a new system under which three-quarters of awards would have been given, instead, on the recommendation of the Prime Minister and State Premiers, with only a quarter to be recommended by the Council as before. The Premiers, if so minded, were then still able to make nominations for Imperial awards, and no doubt this proposal to give them a quota similar to that available for the Imperial awards was an attempt to bring them into the tent. Curiously Sir David believes that if the Council had been abolished and all awards made politically there would have been

\footnotetext{
59 "nothing underhand, so as to take away from every city the zeal for and lusting after honours and distinctions, phenomena which are wont to lead to the overturning of the state" : Cicero, In Verrem, 2.2.132. What happens after nomination is nevertheless, and perhaps inevitably, not a model of transparency. See below, $\mathrm{fn}$ 97. It is also the case that it is preferable for nominees not to be informed of their nomination, and to that extent it is done behind their backs, but this is not a requirement of the law.

${ }^{60}$ Now C.V.O., A.M.

${ }^{61}$ Above $\mathrm{n} 25$ at 44.

${ }^{62}$ Review of Australian Honours and Awards, above n 6 at 267.
} 
nothing to object to, as that would simply have been a change in honours policy which is for the government to determine, ${ }^{63}$ but the mixed system proposed 'would have destroyed the Order of Australia'. ${ }^{64}$ At any rate,

after consultation with the then Chief Justice, Sir Harry Gibbs, who was chairman of the Council for the Order of Australia, the then Governor-General and Chancellor of the Order, Sir Ninian Stephen, went in to bat for the principle upon which the Order had been established. He took the matter up with the Prime Minister and with the relevant minister, pointing out the consequences for the Order of what the Cabinet had done. He also called in the minister's departmental head and made him aware, in no uncertain terms, of the consequences of the bad advice which he and his department had given to Cabinet.

Well, in due course, Cabinet rescinded its decision : the Prime Minister and State Premiers were not given their own honours quotas, and the Order continued to be administered by the Governor-General and his staff, free of ministerial and departmental control, with all recommendations continuing to be made by an independent Council. ${ }^{65}$

This was certainly a remarkable instance of advising, encouraging and warning.

At this point it should be noted that the Chief Justice of High Court of Australia no longer chairs the Council after Brennan C.J. asked for this arrangement to end. Although the equivalent body in Canada still is composed of Richard Wagner C.J. among others, in this country Brennan C.J. took the view that the separation of powers made it undesirable for him or any Justice of his Court to be on the Council. ${ }^{66}$

\footnotetext{
${ }^{63}$ As is also stated by, for example, Hazell, above $n 25$ at 48.

${ }^{64}$ Smith, above $\mathrm{n} 42$ at 79.

${ }^{65}$ Smith, above $\mathrm{n} 42$ at 80 . See also Review of Australian Honours and Awards, above $\mathrm{n} 6$ at 55 . The Australian Archives' catalogue contains, on a quick search, only one item which corresponds more or less to the information given : A13979, 723, dated 14 June 1983 and entitled "Cabinet Decision 723 - Order of Australia Without Submission". However, it was not available for public access at the time of writing. Materials could also be in more general files such as M4520, 44. These are tasks for the future general historian of the Order of Australia.

${ }^{66}$ Bonsey, The Order of Australia : Review 2011 (Government House, Canberra) 2011), p. 20 fn 11; Review of Australian Honours and Awards, above $\mathrm{n} 6$ at 50.
} 
The change was made by Letters Patent in August 1996, ${ }^{67}$ less than eighteen months after Sir Gerard Brennan A.C., K.B.E. became Chief Justice. The chairman (the word used in the Order's constitution, s $4(3)$ ) is now appointed by the Governor-General from among the members - acting on the Prime Minister's advice. ${ }^{68}$ The Council consists of the Vice-President of the Executive Council, ${ }^{69}$ the Chief of the Defence Force, a public servant involved in honours policy ${ }^{70}$ and sixteen governmental representatives : eight are nominated by the Prime Minister and the others represent each of the eight States and Territories. ${ }^{71}$ It therefore has a total of nineteen members. While, at the time of writing, the web site of the Council states that the Prime Minister's nominees are 'community representatives' ${ }^{72}$ the constitution of the Order itself is silent about who, exactly, any of the governmentally appointed representatives represent : the elected government? The State as such - the polity? The community in general? This question is not an academic one, as is shown by the rumours just referred to according to which various politicians have attempted to guide the Council's deliberations through their representatives.

There is no known case in which the Governor-General has declined to act upon a recommendation for an award made by the Council of the Order, or the Sovereign has refused approval to a proposed award before that function was removed from her, but as the process is secret we should not necessarily expect to know. ${ }^{73}$ Nominations are made directly to the Governor-General by the Council without the interposition of the government. ${ }^{74}$ Here then is another of those instances in which the Crown

\footnotetext{
${ }^{67}$ Commonwealth of Australia Gazette, 16 August 1996, no. S303 (C2010Q000044).

${ }^{68}$ Hazell, above $\mathrm{n} 25$ at 47, who additionally records that appointments to the Council are also made on advice. If the Order were established under an Act, s 18B of the Acts Interpretation Act 1901 (Clth) would authorise variation in the chairman's title to accommodate holders who prefer the titles chair, chairwoman or chairperson. No objection could possibly be taken to taking this step even without authorisation to do so, but here is an example of a slight quibble that could arise because of the unusual source of the Order's constitutional arrangements. A more serious example is noted in the text below at $\mathrm{n} 117$; another is noted above, $\mathrm{n} 36$.

${ }^{69}$ Or, under s 4 (4) (a) of the Order's constitution, 'another member of the Federal Executive Council under summons [i.e. another Minister or parliamentary secretary] chosen, in accordance with arrangements made by the Governor-General, to act in the member's place as a member of the Council'.

${ }^{70}$ Under the Council Ordinance of 14 April 1983 (Federal Register of Legislation, C2009Q00096) this should be the secretary (permanent head) of the Department of the Special Minister of State. Such a minister still exists but the eponymous Department has not for many years. It may be that this Ordinance has been superseded by a later one which has not yet made it to the Federal Register of Legislation, although it is also printed in the booklet referred to above, fn 22; it seems likely therefore that the matter has been overlooked. The present representative of the federal public service is Stephanie Foster P.S.M., Deputy Secretary, Governance Group, Department of the Prime Minister and Cabinet.

${ }^{71}$ This securing of regional balance is a distinct strength of the Council also, which Canada's equivalent body lacks : McCreery in in Jackson (ed.), above $\mathrm{n} 55$ at 105.

72 https://www.gg.gov.au/australian-honours-and-awardsorder-australia/council-order-australia

${ }^{73}$ See above, fn 10, for a case interpreting s 6A of the Freedom of Information Act 1982 (Clth).

${ }^{74}$ Review of Australian Honours and Awards, above $\mathrm{n} 6$ at 51.
} 
is formally advised otherwise than by responsible ministers. Is there a constitutional convention that that advice will be accepted? Given that this advice is different from the "advice" proffered by ministers responsible to the people through Parliament, its status is necessarily lower : it is not backed by the democratic choice of the people as those providing it have no democratic mandate. ${ }^{75}$ I suggest that the operation of the constitutional system of government in these circumstances does not require a constitutional convention to exist as a normative matter, and in the absence of information about whether the Council's advice has ever been refused and the reasons for doing so such a convention should not be postulated as factual matter. Nevertheless, the high status of the Council and the long history of general acceptance of its recommendations must make it rare for any of its recommendations for the conferral of awards to be rejected. ${ }^{76}$

Under regs. 3 (2) (a) and 5 (5) of the Terminations and Cancellations Ordinance, the Council also advises the Governor-General upon the removal of awards in the general division. However, reg. 3 (3) specifically provides that his Excellency may act on this front without the Council's advice if it is 'appropriate to do so'. Given the comparative rarity of removals, the seriousness of taking that step and the terms of reg. 3 (3), one would expect that the Governor-General would give independent consideration to recommendations by the Council in this respect, although it would also be expected that they would, as a rule, be followed.

\section{b. The second coming of Knighthoods - processes, procedures and principles}

In the first period during which Knighthoods in the Order of Australia were available (1976 - 1986) they were conferred via the usual process - the Council recommended Australian citizens (permanent

\footnotetext{
${ }^{75}$ Cf. Twomey, "Advice to Vice-Regal Officers by Crown Law officers and Others" (2015) 26 PLR 193, 194, and, in relation to Canada, a similar point appearing in McCreery, above $n 55$ at 199-201.

${ }^{76}$ On this point an elaborate set of principles has been worked out in Canada : McCreery, above $n 55$ at 194202; McCreery, "Not the Governor-General's Choice: Canadian Honours and the Butler-Pitfield Principles" (2019) 13 Jo Parl \& Polit Law 67. In Brian Platt \& Marie-Danielle Smith, "Payette Calls Year 1 'Quite a Ride' while Others See it as Turbulent", "National Post" (Toronto), 12 January 2019, p. A7, it is reported that the present Governor-General of Canada has continued to sit in on Order of Canada meetings to watch [the] Advisory Council deliberate on which Canadians should be recognised, despite honours experts and her own staff strongly advising against it.

'There continues to be micro-management and interference in the honours process [...]', one source familiar with the office said.
} 
residents had not yet been added to its brief) ${ }^{77}$ and any honorary awards would have been handled by the government. The only exception to these usual processes was the appointment of Charles Prince of Wales as a Knight in 1981, made by Letters Patent amending the constitution and conferring upon His Royal Highness precedence in the order immediately after the Governor-General ${ }^{78}$ (which could not have been done by any other method). Nevertheless some indication of the Hawke government's anti-Knighthood stance must have been conveyed to the Council in some manner, for we find that no further Knighthoods were granted after the Queen's Birthday list of 1983 until the level of Knighthood was officially removed in $1986 .{ }^{79}$ The Letters Patent doing so were, incidentally, remarkable because they were issued by The Queen not 'at our Court at St James's' in London, as is usual, but 'at our Court at Government House, Canberra' - it was Her Majesty's “Australia Acts” visit.

On the resurrection of Knighthoods in 2014, the precedent of 1976 was ignored. A new section, 8A, was added to the Order's constitution :

8A. Appointments (including honorary appointments) to the Order as Knight or Dame shall be made, with the approval of the Sovereign on the recommendation of the Prime Minister, by Instrument signed by the Governor-General and sealed with the seal of the Order.

In case this message was missed, the Council's remit was changed to exclude specifically appointments of Knights, and s 19 (1) permitting members of the public to propose awards to the Council was also disapplied to the Knights. It is also noticeable that a requirement for The Queen's approval, long since dispensed with for the other ranks, was specifically mentioned in this new provision ${ }^{80}$ and in answer

\footnotetext{
77 That occurred in 2016 : Commonwealth of Australia Gazette, 11 October 2016, C2016G01347.

${ }^{78}$ Commonwealth of Australia Gazette, 27 March 1981, no. S53 (C2010Q00036). See further on this knotty point Commonwealth Senate, Finance and Public Administration Committee - Estimates, Debates, 23 February 2015, p. 82. This award, unlike that to his father a generation later, 'created no fuss' : Patrick, above n 3 at 113.

79 Commonwealth of Australia Gazette, 11 March 1986, no. S101 (C2010Q00037). Sir Gordon Jackson, previously A.C., was promoted to Knight of the Order in June 1983, after the election of the Hawke government. Presumably this was because the award had already been approved by The Queen and/or communicated to him before the change of government. For a negative reaction to the removal of Knighthoods, see Fox/Furphy, "The Politics of National Recognition : Honouring Australians in a Post-Imperial World" (2017) 63 Aust Jo Pol \& Hist 93, 102.

${ }^{80}$ Nevertheless, the announcement of the awards (not published in the Gazette) began : 'The Governor-General is pleased to announce the following appointments and awards :' (for example,
} 
to a parliamentary question the Prime Minister stated that Her Majesty's approval would be sought. ${ }^{81}$ A limit of four Knighthoods per year was imposed, under s 11B; this did not include honorary appointments, and also did not include the Governor-General, who ex officio was to be the Principal Knight or Dame (s 2 (1) of the constitution). The limit of four was only twice the number allowed in 1976, when the population was much smaller and Imperial awards including Knighthoods were still available.

While self-restraint was evidently practised on that front, there was no public explanation of why the ordinary, time-honoured and best-practice process for the Order of Australia involving the independent Council had been bypassed for its highest and most prestigious level, ${ }^{82}$ nor was any legitimate reason obvious - to put it mildly. Whether any latter-day Sir David Smith made any protest against the breach of the independence principle at the time must be left to revelations in decades hence, but opportunities for such rear-guard actions must have been limited because the idea was not taken to Cabinet. ${ }^{83}$ I do not suggest that Knighthoods themselves should have been the subject of bureaucratic attempts at blocking, for there may be legitimate differences of opinion on them and their re-introduction affects no important politically neutral principle, but it would have perfectly legitimate for something to be done to defend the important principle of the independence of the Order from political interference.

After the Prince Philip controversy, the constitution was amended, in accordance with a promise by the Prime Minister designed to limit the political damage to himself, to give the power to award Knighthoods to the Council, and s $8 \mathrm{~A}$ in particular was repealed. ${ }^{84}$ However, no further appointments at this level were made before the change of leadership resulted in its complete abolition. ${ }^{85}$ The change to appointments by the Council would not, admittedly, have saved anyone from a further Philip-style blunder, for that award was made by the overriding method of amendments to the Order's

\footnotetext{
http://old.gg.gov.au/sites/default/files/files/honours/qb/qb2014/Gazette\%201\%200rder\%20of\%20Australia.pdf). Cf. above, fn 42.

${ }^{81}$ Senate Question No. 350 of 2014.

82 Senator Penny Wong's Senate question no. 349 of 31 March 2014 asked why this method was chosen. The answer provided did not state any reason, but merely that no further information would be given about advice tendered by the Prime Minister to The Queen.

${ }^{83}$ See below, fn 90.

${ }^{84}$ Commonwealth of Australia Gazette, 13 April 2015, C2015G00523. in October 2019, Mr Abbott stated that it had been an error in the first place to give the power to award Knighthoods to the Prime Minister : Troy Bramston, "Turnbull's Ambition was My Undoing, Says Abbott", "The Australian", 7 October 2019, p. 1. ${ }^{85}$ Office of the Official Secretary to the Governor-General, The Australian Honours and Awards Branch, Report 2012-16 (The Office, Canberra 2016), p. 10.
} 
constitution so that Prince Philip was not outranked within the Order by his own son, Prince Charles; ${ }^{86}$ and, as the recipient was not an Australian or permanent resident, the appointment would even aside from that extraordinary procedure not have been made by the Council. This belated change was however a recognition that an important principle of the Order of Australia had been breached and needed to be restored, as well as a serious reflection on the Prime Minister's judgment. Never, perhaps, has any decision, in itself trivial as this one was, better illustrated the need for consultation and frank debate within the government, given the extreme lack of proportion between the significance of the decision as a matter of world history and the enormous level of damage caused to the Prime Minister by it.

Although he did promise in 2014 (before the Prince Philip debacle) to consult with the chairman of the Council before making recommendations for Knighthoods, ${ }^{87}$ the Prime Minister was not required by $s 8 \mathrm{~A}$ to consult anyone - recommendations apparently, based on the terms of $s 8 \mathrm{~A}$, were to be made directly from him to The Queen. The Governor-General and the chairman of the Council were consulted about the appointment of Prince Philip ${ }^{88}$ but apparently no-one else was consulted, and in particular no Cabinet ministers (or none who wished to own up to it after the event). The Prime Minister stated in Parliament merely that '[a]wards in the Order of Australia have never gone to Cabinet $^{\prime 89}$ - true in principle, but of course only because awards were usually handled by an independent Council! (Admittedly this did not apply to honorary awards, but then we may ask : is it really true that Cabinet has never considered the question of honouring a particular distinguished foreigner who is about to visit or be visited?) It would seem that the statement just quoted also means that no consultation occurred, at least with Cabinet, in relation to the other appointments either - alongside the two Governors-General, whose appointments were ex officio, those of Professor the Hon. Dame Marie Bashir A.D., C.V.O. and Sir Angus Houston A.K., A.C. (Mil.), A.F.C.

\footnotetext{
${ }^{86}$ Commonwealth of Australia Gazette, 30 January 2015, C2015G00155; Commonwealth Senate, Finance and Public Administration Committee - Estimates, Debates, 23 February 2015, p. 82. For Prince Charles's appointment by a similar method, see above, fn 78 .

${ }^{87}$ Answer to Senator Penny Wong's Senate question no. 350 of 31 March 2014, para. 5.

${ }^{88}$ Commonwealth Senate, Finance and Public Administration Committee - Estimates, Debates, 23 February 2015, pp. 83, 91; 24 February 2015, pp. 5-7.

${ }^{89}$ Commonwealth Parliamentary Debates, House of Representatives, 23 February 2015, p. 888.
} 
The restoration of Knighthoods itself, notoriously, as a "captain's call" did not go to Cabinet, although Senator the Hon. George Brandis A.-G. Q.C. was consulted. ${ }^{90}$ When the decision was hurriedly made in 2015 to restore the Council's role, it appears that this too was a "captain's call" and the GovernorGeneral's official secretary heard of the change when it was publicly announced by the Prime Minister. The Official Secretary to the Governor-General professed in public not to find this odd, given that honours policy was a matter for the government. ${ }^{91}$ That must of course be the case, given that advice is taken by the Governor-General on all manner of issues, some even arguably weightier than honours, and it is not for unelected Viceroys to run their own honours policy. ${ }^{92}$ There are also no honours in the personal gift of the Governor-General in Australia comparable to the Order of Merit or the Royal Victorian Order which are in the personal gift of The Queen as distinct from being conferred on someone's "advice". Moreover, we have seen that Sir David Smith complained of an earlier failure to consult - so it was not the only time Yarralumla's consent had been assumed rather than obtained. But it cannot be desirable to proceed thus; there is no harm in asking, and the day-to-day administrators of the honours system in Government House may conceivably have something useful to contribute. At all events, that possibility cannot be ruled out without asking them. It is also required by plain ordinary courtesy. Here, however, the circumstances of the appointment of Prince Philip followed by the public reaction and an imminent leadership challenge are no doubt largely to blame for the lack of consultation. There was an urgent need to be seen to be doing something. It was, nevertheless, noticeable that the abolition of Knighthoods under the Turnbull regime, admittedly not as urgent as doing something to calm down the "Sir Prince Philip" outcry, was accompanied by an elaborate demonstration that the matter had gone to Cabinet and been properly endorsed there. ${ }^{93}$

\footnotetext{
${ }^{90}$ Errington/van Onselen, Battleground: Why the Liberal Party Shirtfronted Tony Abbott (Melbourne U.P., 2015), p. 92; Hobbs, “Putting the 'Queen' Back into Queensland" (2014) 39 Alt L 9, 11. It would seem that even the Governor-General may not have been consulted : Commonwealth Senate, Finance and Public Administration Committee - Estimates, Debates, 23 February 2015, pp. 87-90. The letters released under F.O.I. laws referred to there may be found on the Department of Prime Minister and Cabinet's F.O.I. disclosure log web page under the number FOI/PMO/2014/012. They are not particularly illuminating. The background here, of course, is political allegations that the Prime Minister's chief of staff was exercising too much power. That is outside the scope of this article.

${ }^{91}$ Commonwealth Senate, Finance and Public Administration Committee - Estimates, Debates, 24 February 2015, pp. $8 f$.

${ }^{92}$ This is also the case in Canada : McCreery, above $\mathrm{n} 55$ at 201.

${ }^{93} \mathrm{See}$, for example, https://www.abc.net.au/news/2015-11-02/knights-and-dames-to-be-scrapped/6904474, where Senator the Hon. Mathias Cormann is quoted thus : 'It's a Cabinet decision, it's not just a decision by Malcolm Turnbull'.
} 


\section{Comparisons and cases : Canada and New Zealand}

\section{a. Canada - honours and the Courts}

As noted earlier, the Order of Australia was established not as a copy, but on the model of the Order of Canada. Prince Philip was appointed an Extraordinary Companion of the Order of Canada, its highest level, in 2013. ${ }^{94}$ No temptation to create Knighthoods in that Order appears ever to have seriously presented itself. ${ }^{95}$ While the Order of Canada's history has hardly been entirely free of drama, ${ }^{96}$ there is perhaps one area in which Canada excels, and that is in the provision of case law following litigation on topics relating to the honours system. ${ }^{97}$

The cases concern the important topic of the extent to which decisions relating to honours can be judicially reviewed. In line with an obiter dictum in the House of Lords, ${ }^{98}$ in Black v. Chretien ${ }^{99}$ the $^{2}$ Court of Appeal for Ontario held that decisions in the exercise of the prerogative of honours were beyond the review of the Courts. The facts were somewhat unusual : the plaintiff, now Lord (Conrad) Black of Crossharbour, was in line for a British peerage which was blocked after objections raised by the Canadian Prime Minister, the defendant, with the British Prime Minister. ${ }^{100}$ Even though it was

\footnotetext{
${ }^{94}$ Canada Gazette, Part I, 6 July 2013, p. 1766. Sub-section 9 (2) of the Order's Constitution provides, inter alia, that 'a member of the Royal Family may be appointed as an extraordinary Companion, Officer or Member' : Canada Gazette, Part I, 20 July 2013, p. 1862. Dr Christopher McCreery has advised me by e-mail that Prince Philip

had first been nominated in 1967/68 and was only admitted after the issue of adding an extraordinary division to the Order was resolved (as part of the 2012 review I did of the national honours system for the Prime Minister's Office and Privy Council Office). When the appointments were announced great pains were gone to ensure that the world knew that H.R.H. had been nominated through the normal channels, and there was an actual citation attached. In 1982 the then government offered to make H.R.H. a C.C. just for being the spouse of the Sovereign and Her Majesty patently refused. While H.R.H. was admitted as an extraordinary Companion and Commander, he was nominated and written up just like all the other members of the Order of Canada and Order of Military Merit -- and a detailed citation was published as to why he was getting it.

95 McCreery in Jackson (ed.), above $\mathrm{n} 55$ at 105.

96 There is a general history in McCreery, above $\mathrm{n} 55$.

${ }^{97}$ That is not to say that Australia has no such cases. Reference has already been made to Kline, above n 10, on the inapplicability of the F.O.I. laws to documents held by the Official Secretary to the Governor-General relating to nominations for awards in the Order of Australia.

${ }^{98}$ Council of Civil Service Unions, [1985] AC 374, 418.

99 (2001) 54 OR ( $\left.3^{\text {rd }}\right) 215$.

100 In response to the memoirs of the Canadian Prime Minister in question, Lord Black puts his side of the story in a recent newspaper article : "As I Recall ...", "National Post", 8 December 2018, p. A19.
} 
claimed that this action occurred for an improper purpose - indulgence in a personal vendetta; the plaintiff was a newspaper publisher - the Court held that it would not interfere for the reason stated. This was because no-one had a right to an honour nor a legitimate expectation of receiving one and the award of an honour involved no liberty, property or economic interests. ${ }^{101}$ It is, of course, no longer in order to say that the source of a power in the prerogative renders it exempt from judicial review, but yet some prerogative powers are of a nature which makes them unsuitable for curial oversight and/or renders such oversight unnecessary.

While some of the reasoning in Black is certainly open to question ${ }^{102}$ - a chat between two Prime Ministers in itself alters no legal rights and no more needs the support of the Royal prerogative than does cooking the prime ministerial lunch in the official residence ${ }^{103}$ - the Court of Appeal for Ontario came to the correct conclusion on the facts in front of it for the reasons stated. One writer who, in line with modern authority initiated by Council of Civil Service Unions v. Minister for the Civil Service, ${ }^{104}$ deprecates categorical subject-matter exemptions for particular fields of government activity has suggested that, even if decisions to grant or withhold honours are justiciable, there would at most need to exist 'a rational and impartial process for candidates to be identified and considered'. ${ }^{105}$ Given that such a thing exists in both Canada and Australia, there is no need for any further judicial oversight. (Arguably, however, in the United Kingdom such an institution has existed only since the Honours Committees were set up in $2005^{106}$ - yet it was never suggested there that the lack of such a thing made decisions not to grant honours susceptible of judicial review. And there is always room for arguing that a process is not quite rational or impartial enough.) As there is no statute involved, there is also no room for the commonly heard rationale that Parliament must have intended the power to

\footnotetext{
${ }^{101}$ At [60] - [62].

102 See, for example, Klinck, "Modernising Judicial Review of the Exercise of Prerogative Powers in Canada" (2017) 54 Alberta LR 997, 1004.

103 On this point, there is an interesting and thoughtful English essay : Tomkins, above $\mathrm{n} 8$.

104 [1985] AC 374. It is surprising to find that, after a third of a century, this decision has not been expressly approved by the High Court of Australia, but it is very reasonable to assume that it is applicable here : Aronson/Groves/Weeks, Judicial Review of Administrative Action and Government Liability (6 ${ }^{\text {th }}$ ed., Law Book, Pyrmont 2017), p. 125.

In $R$ (ex rel. Miller) v. Johnson [2019] 3 WLR 589, the Supreme Court of the United Kingdom, in concluding that the decision to prorogue Parliament under the prerogative was justiciable, emphasised its important political and constitutional consequences (at 604-608). This reasoning aligns with the main point made by the Court of Appeal for Ontario cited in the text, namely that refusing honours should not be justiciable because no legal interest is affected by it.

105 Klinck, above $\mathrm{n} 102$ at 1025.

${ }^{106}$ Even they were not statutory, as an enquiry had recommended : McKeown/Thomson, above $\mathrm{n} 4$ at 84 . See further Heydel-Mankoo, "Reform of the United Kingdom Honours System : An Analysis of Recent Developments" in Jackson (ed.), above n 25, ch. 8.
} 
be exercised in accordance with the rules of procedural fairness. Finally, 'there is no satisfactory legal yardstick by which the issue can be resolved'107 - who is to say, as an objective matter, whether a person deserves no honour or an honour of a particular, and if so which grade? It is true that ss 12 (1), 15 (1), 17 (1) and 18A of the Order of Australia's constitution contain general descriptors of the sort of service for which membership in it should be awarded. For example, under s 12 (1) 'Appointments as Companions or honorary Companions in the General Division shall be made for eminent achievement and merit of the highest degree in service to Australia or to humanity at large', whereas for Officers 'distinguished service of a high degree to Australia or to humanity at large' is required. Quoting these, however, merely emphasises the lack of legally assessable standards. For all these reasons, the better course, given that honours do not provide anything beyond symbolism - 'no legal right of the citizen is engaged whether in public or private law'108 - and much of the process must occur in secret anyway, ${ }^{109}$ is to agree with the Court that the process of awarding honours, at least, is outside the realm of judicial review. What sort of person, anyway, would be found in Court arguing for the grant of an honour?

Lord Black avoided the problem in the end by renouncing his Canadian citizenship and thus depriving the Prime Minister of that country of the right to object to his ennoblement. His next move on the honours front was to have himself convicted and sent to prison for crimes in the United States of America, following which proceedings were started to deprive him of his appointment as an Officer of the Order of Canada. ${ }^{110}$ Thereupon he claimed the right not merely to make submissions on the question to the Advisory Council, but also to appear in person before it in order to present his case. He claimed that legitimate expectations were created by the published policy on the termination of appointments ${ }^{111}$ (the equivalent of our Terminations and Cancellations Ordinance). In a brief decision ${ }^{112}$

\footnotetext{
107 Curtis v. Minister of Defence [2002] 2 NZLR 744, [27].

108 Shergill v. Khaira [2015] AC 359, 378.

109 See above, fn 73.

${ }^{110}$ Section 3 of the House of Lords Reform Act 2014 (U.K.) was passed partly against this same background, but see s 3 (9) relating to overseas convictions. Lord Black is currently listed as being on leave of absence from the House, and it would seem that there has been no resolution of the House under s 3 (9) requiring the Lord Speaker to act against Lord Black. Even such action, however, would not deprive his Lordship of his title; he would merely become a peer who is not eligible to take part in the sittings of the House. Only an Act of Parliament (e.g. Titles Deprivation Act 1917 (U.K.)) can deprive a peer involuntarily of that dignity.

It should also be noted that, on 15 May 2019, his Lordship received a presidential pardon for the offences of which he was convicted: Donald Trump, "Executive Grant of Clemency", <https://www.justice.gov/pardon/page/file/1163776/download>.

${ }^{111}$ This is available at https://www.gg.ca/en/honours/canadian-honours/order-canada/constitution. It is clearly much more elaborate than our Ordinance and does not leave to guesswork, for example, the question whether the proposed victim may make representations, not merely an objection : it says so explicitly. 112 Black (Lord) v. Advisory Council for the Order of Canada [2013] FCA 267.
} 
the Federal Court of Appeal held that there was no question of Lord Black's credibility that would make it desirable for him to be seen in person and dismissed the claim. Australian case law certainly supports the proposition that there is no general right to an oral hearing, and the question is a practical one depending on the facts of the case, which may include any undertakings made by the authorities about the course of proceedings and any need to see the person affected in order to assess credibility. ${ }^{113}$ On the facts of Lord Black's case, there certainly did not seem to be any type of serious foothold, either by reason of undertakings or by reason of the nature of the case against him, for the argument that he should have the opportunity of a personal appearance. The Judges however did not express a view on the questions of justiciability or even the existence of a legitimate expectation.

If the question of justiciability relating to terminations and cancellations of awards is ever fairly raised, what should the law be? Depriving someone of an honour granted is a step of such gravity, particularly for reputational purposes, that review by the Courts is warranted and the question should be justiciable. If someone does not receive a proposed honour, hardly anyone will even know (unusual cases involving litigious Canadians, peerages and international negotiations aside). On the other hand, in Australia the deprivation of an honour must receive publicity in the official gazette at least under reg. 7 of the Terminations and Cancellations Ordinance. Furthermore, there is an evident difference in principle between not honouring someone with an award and removing an award already granted. Unlike the dismissal of a minister dealt with in Stewart v. Ronalds, ${ }^{114}$ such a step does not raise matters of a political nature in the narrow or high sense, and there are clear legal standards for the removal of an award set out in the Terminations and Cancellations Ordinance such as being convicted of a criminal offence, obtaining an award by misrepresentation or committing disreputable acts. Even leaving aside the concept of legitimate expectation, therefore - which Australian case law certainly requires us to $\mathrm{do}^{115}$ - the deprivation of an honour is in and of itself justiciable and procedural fairness at least is required.

This conclusion requires the somewhat spare wording of our Terminations and Cancellations Ordinance to be interpreted accordingly : thus, the right to lodge an objection must be read as the right to lodge an objection that is supported by reasons (not merely a bald statement to the effect that "I, the recipient of this award, object to the proposed termination of it; signed A.B.") and also to have those

\footnotetext{
${ }^{113}$ Minister for Immigration and Border Protection v. “W.Z.A.R.H.” (2015) 256 CLR 326, 336-339, 341, $343 f$.

114 (2009) 76 NSWLR 99.

115 “W.Z.A.R.H.”, (2015) 256 CLR 326, 334f, 343.
} 
reasons properly considered by the Council or the Governor-General (which does not of course mean that thousands of pages of material can be submitted). No doubt that conclusion simply reflects current practice in the very few cases in which terminations are considered, ${ }^{116}$ but it is comforting to know that a footing, although perhaps not the firmest imaginable, can be found for it in the Ordinance as well as in the common law. Probably, too, in the most unlikely event that an award were terminated for a reason not set out in the Terminations and Cancellations Ordinance or for an improper purpose, on irrelevant considerations etc. a declaration to that effect would be available, although such a case is extremely unlikely to arise in practice and need not be further pursued here. Unfortunately, however, s 13 of the Administrative Decisions (Judicial Review) Act 1977 (Clth) would not apply, as there is no decision under an enactment as distinct from an instrument made under prerogative power, and accordingly the common-law rule applies : there is no legal duty to give reasons. ${ }^{117}$

In the final Canadian case, Drabinsky v. Advisory Council of the Order of Canada, ${ }^{118}$ the plaintiff claimed to have a legitimate expectation of an extension of time to put his submissions against the cancellation of his award so that he would be able to prepare materials after his release from prison, but there was nothing in the materials to support such an extension. The policy in question did permit extensions to be granted - another omission in our own, so carefully drafted Terminations and Cancellations Ordinance - but it certainly made no promises that they would be granted. Accordingly, even assuming the question was justiciable (on which the Court again did not commit itself), no legitimate expectation could have arisen. The Court also held that there was no duty to give reasons for the termination of an award nor anything in the policies that would support a legitimate expectation to that effect. This is a fortiori true of our Terminations and Cancellations Ordinance and given the state of our case law.

\footnotetext{
${ }^{116}$ Office of the Official Secretary to the Governor-General, above $n 85$ at 92, states : 'The process requires that the member is given the opportunity to respond to any allegations before a recommendation is made by the Council to the Governor-General. Any response is provided to the Council for consideration.' On the following page we learn that there have been forty-two terminations from 1992 to 2016, an average of under two per year.

117 In addition, the Ombudsman cannot act, as the Office of the Official Secretary is not a department within the meaning of s 5 (1) (a) of the Ombudsman Act 1976 (Clth).

118 [2015] FCA 5.
} 


\section{b. New Zealand - Knighthoods across the ditch}

One of the most curious aspects of the restoration of Knighthoods in 2014 and the "Sir Prince Philip" controversy in 2015 was the absence of much reference to the position in New Zealand. Unlike Australia, New Zealand has two orders, ${ }^{119}$ both created, for some reason, by the slightly less grand method of a Royal Warrant. The older and more prestigious is the Order of New Zealand, which, like the Order of Merit (a Commonwealth award which originally is British) ${ }^{120}$ on which it was partly modelled, carries no titles but only the post-nominal "O.N.Z.". ${ }^{121}$ It is limited to only twenty members. ${ }^{122}$ The second order, the New Zealand Order of Merit, however, was originally created in 1996 with five levels, the two highest of which were Knights; there may be fifteen junior Knights appointed per year, far more than the four allowed by the Abbott changes in Australia, to which are added no more than thirty of the more senior level of Knights alive at any one time. ${ }^{123}$ While these titles were removed under the Labour government only four years after the Order's creation, in $2000^{124}$ - partly so as not to overshadow the more prestigious, but titleless Order of New Zealand, and partly because of dislike of the

\footnotetext{
${ }^{119}$ This is to omit the Queen's Service Order, a smaller Order but actually older, having been instituted in 1975 like the Order of Australia. It is not considered here as it has never conferred a titular distinction and its membership is comparatively small. However, three members of the Royal Family are also Companions of this Order, including Prince Philip.

${ }^{120}$ Full members may include persons from any country of which The Queen is Sovereign, and at the time of writing two former Commonwealth prime ministers were members : the Rt Hon. Jean Chrétien P.C., O.M., C.C., Q.C. and the Hon. John Howard O.M., A.C. The same criterion of eligibility exists for both New Zealand orders, which under their statutes are available not merely to citizens of New Zealand, but to anyone whose Sovereign is The Queen. According to one commentator, 'New Zealand has correctly understood that Commonwealth citizens share a common bond and should not be regarded as alien', although it may be countered that this understanding evidently applies only to citizens of Her Majesty's realms and not to the republics within the Commonwealth : Heydel-Mankoo, "Assessing the Honours of New Zealand - An Example for Canada" in Jackson (ed.), above n 25 at 131. See further O'Shea, "New Zealand Honours" in Jackson (ed.), above n 25 at 60, $62 \mathrm{f}$.

${ }^{121}$ Statutes of the Order of New Zealand, SR 1987/67, cl. 15.

${ }^{122}$ Statutes of the Order of New Zealand, SR 1987/67, cl. 4.

${ }^{123}$ Statutes of the New Zealand Order of Merit, SR 1996/205, cl. 9.

${ }^{124}$ Additional Statutes of the New Zealand Order of Merit, SR 2000/84; existing holders of the titles were not affected, but new titles could not be conferred.
} 
titles as anti-egalitarian ${ }^{125}$ - in 2009 they were reinstated by the conservative government led by John Key - now Sir John. ${ }^{126}$

A survey of the reaction to the restoration of 2009 indicates a mixed reception, with many voices in favour as well as against; ${ }^{127}$ there was nothing like the incomprehension, hostility and ridicule that greeted the second coming of Knighthoods in Australia five years later. According to one commentator, Key's 'popularity rose, in part because everyone who had been given a lesser award was allowed to upgrade to a Knighthood or Damehood. By co-opting a whole class of community leaders, the critics were disarmed. ${ }^{128}$ I am not sure that the ordinary New Zealander would have been much impressed by that aspect of the change, but at any rate such a step was not available in Australia : in New Zealand it could be done because the two highest levels of the New Zealand Order of Merit were still awarded. Awards from 2000 to 2009 were not 'lesser' but had simply been renamed and stripped of the titular distinction. But in Australia, on the other hand, a separate category above the existing ones was created in order to re-introduce Knighthoods, and it would hardly have been rational to upgrade all A.C.S for the previous forty years to Knighthoods and invidious to divide forty years of recipients into two classes or select a later cut-off date for any such step. ${ }^{129}$ At any rate, the present Labour government in Wellington has shown, to date, no inclination to restore the position adopted by its predecessor in 2000.

\footnotetext{
${ }^{125}$ Fox, above $\mathrm{n} 2$ at 217f; Fox, “An 'Imperial Hangover'? Royal Honours in Australia, Canada and New Zealand, 1917 - 2009" (2014) 7 Britain \& the World 6, 13; O'Shea, above $n 120$ at 62. The first reason given in the text, not overshadowing the O.N.Z., was the reason given for preferring, 'not [...] without regret' (p. 12), a titleless O.N.Z.M. in the report of the Prime Minister's Honours Advisory Committee, The New Zealand Royal Honours System (Cabinet Office, Wellington 1995), pp. 12f, 72-74.

${ }^{126}$ Additional Statutes of the New Zealand Order of Merit, SR 2009/90. Those who had received the two highest levels after 2000 were eligible to be re-designated as Knights or Dames, and even widows of deceased gentlemen in that category became eligible to apply for the courtesy title "Lady".

${ }^{127}$ Fox, above $\mathrm{n} 2$ at 223-225 (including positive reaction from the republican movement in New Zealand); Fox, above $\mathrm{n} 125$ at $24-26$.

128 Patrick, above $\mathrm{n} 3$ at 113.

${ }^{129}$ Following New Zealand's decision was also specifically ruled out by Mr Abbott in a press conference recorded in "P.M. Transcripts : Transcripts from the Prime Ministers of Australia", i.d. no. 23367, at :

http://pmtranscripts.pmc.gov.au/release/transcript-23367. In October 2019, reflecting on his time in office, Mr Abbott declared that he 'should have found a way' of following New Zealand's lead and upgrading past honours to Knighthoods but did not say how the practical problems of doing so could have been mastered: Troy Bramston, "Turnbull's Ambition was My Undoing, Says Abbott", "The Australian", 7 October 2019, p. 1
} 
Not only that : in 2012 Prince Philip was made a member of the Order of New Zealand, 'for services to New Zealand' as the citation ran. ${ }^{130}$ While this was not a Knighthood strictly so called, it was an appointment to the most prestigious Order that New Zealand had to offer, and the citation might be thought particularly incongruous : in Australia there was, perhaps mercifully, no citation owing to the special method - an amendment to the Constitution of the Order of Australia - adopted for conferring a Knighthood in the Order of Australia upon His Royal Highness. ${ }^{131}$ As was only to be expected, in New Zealand there was criticism of this appointment from republican quarters, but only a little, ${ }^{132}$ and also some support $\mathrm{t}^{133}$ - again nothing like the reaction when a comparable step occurred three years later across the Tasman. Perhaps another reason for this was that the failure of Mr Key, as he then was, to consult his colleagues about this step 'was out of character for him. Unlike Abbott, Key didn't need advice about such basic political skills as listening to colleagues. ${ }^{134}$

Strikingly, there is no Council for either order in New Zealand : in both cases nominations are made by the Prime Minister or other Minister. ${ }^{135}$ The idea of a council was rejected when the Order of New Zealand Merit was instituted on the grounds that advisory councils were not perfect either, public nominations were already permissible in New Zealand and this fact simply needed better publicity, the introduction of a new honours system was not the time for a significant change in procedures, the existing system had mostly been successful anyway, and 'governments have the most powerful of reasons for preparing balanced lists that will win public approval, and that is the scrutiny of Parliament and people'. ${ }^{136}$ While the award of a Knighthood to Prince Philip certainly indicates that this scrutiny can occur, it is not the case that governments will usually stand or fall by every entry in the honours lists. Public nominations are still accepted in New Zealand and there is now an application form for the purpose, but only a cabinet committee to consider the granting of awards. That is certainly not an example that Australia should follow.

\footnotetext{
130 New Zealand Gazette, 29 June 2012, p. 2091.

131 See above, fn 86.

132 Patrick, above $\mathrm{n} 3$ at 113.

${ }^{133}$ See, for example, Nicholas Jones, "O.N.Z. Makes the Duke a Top Kiwi”, “New Zealand Herald”, 4 June 2012 , p. A1.

${ }^{134}$ Errington/van Onselen, above $\mathrm{n} 90$ at 128.

135 Statutes of the Order of New Zealand, SR 1987/67, cl. 10; Statutes of the New Zealand Order of Merit, SR 1996/205, cl. 11.

${ }^{136}$ Prime Minister's Honours Advisory Committee, above n 125 at 76.
} 


\section{Conclusions}

It may be safely conjectured that Tony Abbott's experiment with the re-introduction of Knighthoods has killed them off in this country forever, or at least for a very long time. ${ }^{137}$ In theory a conservative government could attempt to repeat the Abbott move, but as long as memories of the Knighthood to Prince Philip remain alive it is most unlikely to do so. The Australian Labor Party, for its part, has long led resistance to titles, although its sister party in the United Kingdom is currently led by a Knight of the Realm and its record was patchy until recently : while its platform contained a plank opposing Imperial (and thus titular) awards since 1918, assorted Labor governments sometimes broke with this stance. ${ }^{138}$ No modern example of such behaviour exists, however; the Labor Party's stance nowadays is quite clear, and it was responsible for the removal of Knighthoods from the Order of Australia in 1986, although this step was not greeted at the time with universal acclaim. ${ }^{139}$

Not everyone will contemplate the end of Knighthoods without a tinge of regret that such appalling and insensitive marketing has now rendered them virtually a taboo in Australian public life. They are a distinction that is understood and respected internationally and an adornment of various offices such as Governor-General and Chief Justice that still sometimes seems conspicuous by its absence. We often hear about the need to adapt ourselves to the customs of the Asia/Pacific region, and there Knighthoods are an indulgence that various societies permit to themselves : as well as New Zealand's home-grown Knighthoods, in Malaysia the title "Datuk" is comparable to Knighthoods, and Imperial Knighthoods remain available in Papua New Guinea, our former colony, 'on the advice of Her Majesty's Papua New Guinea Ministers'. ${ }^{40}$ The form of address consisting of "Sir" or "Dame" plus first name is also a happy and convenient compromise, in speaking to the great and the good, between the stiffness of $\mathrm{Mr} / \mathrm{Ms}$ etc plus surname and the excessive informality of just the first name alone. Finally, they are a worthy reward to and inducement for philanthropists, such as those who gave the money to found

\footnotetext{
137 See above, fn 79.

${ }^{138}$ Fox, above $\mathrm{n} 2$ at 212f; Fox, above $\mathrm{n} 125$ at 11; Fox/Furphy, above n 79 at 97; Review of Australian Honours and Awards, above $n 6$ at 13; Whitlam Q.C., above $n 17$ at 139f. See also the Labor-inspired motion in New South Wales Parliamentary Debates, Legislative Assembly, 25 September 1923, pp. 1068-1078.

139 See above, fn 79.

${ }^{140}$ E.g. London Gazette, 8 May 2017, p. 9404 - G.C.M.G. for the Governor-General.
} 
the University of Adelaide and more or less in return received the title "Sir" ${ }^{141}$ - an exchange which both parties to it considered excellent value.

In addition, '[f]or some Australians, the withdrawal of British honours appears to have created a void which Australian honours have failed to fill' reported the Review of Australian Honours and Awards ${ }^{142}$ after conducting a wide public survey in October 1994. The same review received twenty-eight suggestions for the reinstatement of Knighthoods or titles - it was among the top ten suggestions received from the public - although three others took the trouble to make a stance against that very thing ${ }^{143}$ and the Review's sense was that 'the overwhelming public opinion was strongly against Knighthoods'. ${ }^{144}$ At that point, of course, the memory of Imperial titles was twenty years fresher than it was in 2014, although that was not necessarily a positive thing given the dubious character of some of the people knighted in Queensland, for example. Nevertheless, there is still some evidence that the absence of Knighthoods is occasionally felt in this country : in December 2018 advocacy from the sporting world for knighting Shane Warne and Dennis Lillee was heard. While it is possible that there is a bit of the larrikin spirit and perhaps not always complete seriousness behind the proposal to knight Mr Warne in particular, it was pointed out that he was the only player not knighted on Wisden's poll of the five greatest cricketers of the twentieth century and this was an injustice that should perhaps be corrected by a Knighthood from The Queen. ${ }^{145}$ There is of course no mechanism now for doing so; rarely, Australians are still knighted in the British list, ${ }^{146}$ but only for services to the United Kingdom such as Mr Warne could not claim - his appearances for English county sides would hardly suffice for a Knighthood - and since Sir David Smith K.C.V.O., A.O. in 1990 there have also been no Australian appointments at Knighthood level to the Royal Victorian Order or to any other Knighthood, such as the Garter, still theoretically available to Australians qua Australians. Certainly, however, Dennis Lillee

\footnotetext{
${ }^{141}$ The reference is to Sir W.W. Hughes and Sir Thomas Elder. Both performed services to South Australia beyond their endowments for the University of Adelaide, and there is no official statement of what the balance was between those other services and their donations to the University in securing them Knighthoods, but it is tolerably clear that their Knighthoods were based in large part on the enormous sums of money they lavished upon the infant University of Adelaide. Sir W.W. Hughes, for example, lived in England from 1873 until his death, but even almost a decade and a half later his obituary in the Times ("Obituary", 7 January 1887, p. 10) began its summary of his life by referring to him as the "Father" of the University of Adelaide'.

${ }^{142}$ Above $n 6$ at 101.

${ }^{143}$ Above $n 6$ at 164 .

144 Above $n 6$ at 187.

${ }^{145}$ Peter Rolfe, "Oh, What a Knight : Push for Warnie to Become 'Sir Shane'”, "Herald Sun" (Melbourne), 22 December 2018, p. 5.

${ }^{146}$ The most recent example is Sir Frank Lowy A.C. As Australians thus knighted are of course subjects of The Queen, even if in a different capacity, they are permitted to bear the title "Sir" or "Dame", which is not available to others.
} 
would have been a better candidate for the revived Australian Knighthoods of 2014 than Prince Philip, from every imaginable point of view!

A further curiosity is that some of those leading the opposition to Knighthoods even before the "Sir Prince Philip" debacle bore much longer and wordier titles such as "Senator the Honourable". Indeed, of the four people who resigned from the Order of Australia in 1976 upon and owing to the first coming of Knighthoods in the Order in that year, three ended their lives with earned or honorary doctorates. ${ }^{147}$ (The exception was Patrick White.)

What it is that makes the one-syllable handle offensive to the taste of so many while honorary doctorates or the eight syllables of "Senator the Honourable" are not? One answer is that each of those eight syllables reflects a distinction conferred, directly or indirectly, by popular election (unlike doctorates), and thus such titles may be considered exceptions to the egalitarian dislike of distinctions among citizens ${ }^{148}$ : these distinctions are conferred by the citizens themselves. Another is that the title "Sir" or "Dame" is conferred in a post-colonial, or perhaps more accurately post-Imperial context in which it appears to compromise the too easily won independence of Australia and its separate national identity - often too close a copy of the old British-Australian identity for comfort and in desperate need of points of distinction. ${ }^{149}$ That aspect was quite evident in the case of the award to Prince Philip, and indeed this perspective provides a slightly more elaborate underpinning for the extreme lack of sense shown in conferring such an award.

Nevertheless, there were also good reasons, needless to say, for the opposition to the restoration of Knighthoods. As well as the obvious objections relating to aping the British and undermining our egalitarian myth that have just been referred to in passing, another is that honours systems have been attempting to adapt to the modern world and as a result 'have increasingly drawn on public nomination and have placed far greater emphasis on recognition of people according to the contribution they

\footnotetext{
${ }^{147}$ Cf. Fox, above $\mathrm{n} 2$ at 216f; Fox/Furphy, above $\mathrm{n} 79$ at $100 f$.

${ }^{148}$ This is an aspect that is elaborated on with much interest and profit by Fox, above $n 2$, who, at 225, refers to the view that titles are quite egalitarian, as long as everyone has a more or less equal opportunity to attain one. Another difficulty with the argument from egalitarianism, besides its status as myth and far from a complete account of our society's actual nature, is that, if equality requires the abandonment of titles, it must also result in the abandonment of post-nominals and the abolition of all honours.

${ }^{149}$ Fox, above $\mathrm{n} 125$ at 7; Fox/Furphy, above $\mathrm{n} 79$ at $110 \mathrm{f}$.
} 
have actually made rather than the status of the position they hold'. ${ }^{150}$ Clearly an automatic Knighthood for the Governor-General ran contrary to that, although only it was likely that one person would be so honoured every five years and there are still those who find it jarring to hear the GovernorGeneral bear the title "Mr" or "Ms". ${ }^{151}$ However, the new de facto possessor of the power to award Knighthoods, the Hon. A.J. Abbott M.P., in his press conference announcing their restoration explicitly linked the award to the holding of an office - it was to be for 'those who have accepted public office rather than sought it and who can never, by virtue of that office, ever entirely return to private life'; he gave examples such as chief justices and defence force chiefs. ${ }^{152}$ And all Australian appointments in 2014 and 2015 were indeed the "usual suspects", distinguished, it is true, by their outstanding conduct and service, but also on the basis of the offices they held. Where Prince Philip stands in this respect need hardly be stated.

Despite the final demise of Knighthoods in Australia, there are still lessons to be learnt from this episode. One question is why the Order of Australia provides virtually the only remaining example in this country of prerogative legislation. Malcolm Hazell says that parliamentary legislation was avoided as a means for setting up the Order because Letters Patent 'provided a degree of tradition and continuity with the former scheme of Imperial honours and, importantly, maintained the source of authority for the honours system above politics'. ${ }^{153}$

\footnotetext{
${ }^{150}$ Bonsey, above $\mathrm{n} 66$ at 10.

${ }^{151}$ Hence the view of Keith Windschuttle in "Chronicle" (2015) 58:5 Quadrant 4, 5 that "because the Australian honours system introduced by the Whitlam government has so far worked well, any future recommendations for Knights and Dames should be confined solely to Vice-Regal personae'.

This notice appeared in the Commonwealth of Australia Gazette, 8 May 2013, C2013G00681 :

The title 'the Honourable' for Governors-General

Her Majesty The Queen has given approval for the title of 'the Honourable' to be granted to Australian Governors-General.

Governors-General will now be styled 'Her/His Excellency the Honourable' while in office and 'the Honourable' in retirement.

This entitlement applies retrospectively, as well as to the current and future holders of the office. Department of the Prime Minister and Cabinet

The new element is, of course, not the "Excellency" part while in office but the "Honourable" part after leaving it. Comparable decrees were made for the State Governors. However, neither title is in everyday use as "Sir" is or was.

152 "P.M. Transcripts : Transcripts from the Prime Ministers of Australia”, i.d. no. 23367, available at :

http://pmtranscripts.pmc.gov.au/release/transcript-23367

${ }^{153}$ Hazell, above n 25 at 39.
} 
This preserves flexibility, although flexibility also has its perils even for those to whom it is available, let alone to the body politic as a whole. Dr Wayne Errington and Professor Peter van Onselen provide this interesting explanation for the restoration of Knighthoods under Mr Abbott :

Certainly, [the reinstatement of Knighthoods in 2014] was an emotional decision that arose from the constrained policy choices his party and the institutions of democracy presented to him, and over-compensation in the realm where he could exercise the leadership freedom he craved. Abbott's problem was that his realm of leadership freedom was vanishingly small. All his life he had worked loyally within institutions to get to the top and exercise his version of moral leadership. His experience as a political leader had made him painfully aware of how vociferously some of his social views were opposed, which had damaged his self-confidence. The surprising thing about Abbott's government was how little it achieved in the cultural realm given that Abbott himself had worked towards these goals for so long. Re-introducing Knights and Dames was not a lunge from the cliff, but a cry for help. ${ }^{154}$

With some sacrifice of flexibility, such temptations would be removed if a statutory basis existed for the Order of Australia and the Royal prerogative to create further societies of honour were abolished (a step which would not prevent the creation of further stand-alone medals such as those for bravery and long service and those marking important state occasions. Alternatively, existing awards of that type could be "grandfathered" and delegated legislation could be the sole means of establishing further such awards, which would mean that they could be disallowed by either House of Parliament.) If it were thought desirable, or as a selling-point, such legislation could also specifically rule out titular distinctions in the Order of Australia. Such legislation would certainly be a break with the Imperial past, but hardly one even of the significance of discontinuing the wearing of wigs in Parliament, ${ }^{155}$ and it would also not necessarily compromise the status of the Order of Australia as an institution above politics, as Malcolm Hazell feared. Indeed, it is evident that the only major political controversy attaching to the Order of Australia over its more than forty years of existence has been due to its easy amenability to executive fiddling without the need for parliamentary consent. It should not be difficult

\footnotetext{
${ }^{154}$ Errington/van Onselen, above $\mathrm{n} 90$ at 93.

155 There are precedents for such legislation within Her Majesty's realms, such as the National Honours Act 1998 of Antigua and Barbuda.
} 
to draw up legislation for the Order of Australia which would receive bipartisan support; such legislation would of course be assented to by the Crown; ${ }^{156}$ and it would put the Order on a firm basis as an expression of the will of the highest organ of the state, its Parliament. Such legislation would also need to deal with the question of the justiciability of decisions made to withhold or remove awards.

If that proposal is not accepted, or only in the longer term, an issue raised above is whether the Letters Patent including the Order's constitution should continue to be issued from Buckingham Palace or Yarralumla. We saw that there is no legal impediment to transferring the source of the constitutional arrangements from the former to the latter, although for the sake of avoiding arguments a specific authorisation could be procured. Some will prefer the view that the source of all Australian laws, even - or perhaps especially - exercises of the prerogative power, should be located in Australia. However, the awards themselves, which occur twice yearly and are therefore far more prominent than dusty old constitutional documents, are now unequivocally sourced in Australia; Her Majesty's only involvement is in receiving a list of awards after the fact. If her position as Sovereign of the Order is to mean something, it must have some duties attached, and there is little to gain and only prestige to be lost by changing the issuer of the Letters Patent. Perhaps there might also be some small addition to the stability of the Order's constitutional arrangements owing to the extra step involved in seeking approval from London and a small degree of greater reluctance to propose questionable steps to The Queen, although this did not save the Abbott government from embarrassing itself. ${ }^{157}$ There are real concrete advantages in setting up the Order by way of Act of Parliament, but nothing much to be gained and a little that would be lost by moving the Letters Patent from the Royal to the ViceRegal office-holder.

One matter that should be attended to is the role of the federal government's and the States' and territories' representatives on the Council of the Order. As we have seen, ${ }^{158}$ there is no clarity at all about who exactly these people represent - is it the community of the polity concerned, the government or something else? There have even been suspicions expressed by people who should know that such positions have been used - let us say frankly : abused - for the purpose of procuring awards

\footnotetext{
156 If desired, it could even be reserved for Her Majesty's personal assent, although this is certainly not constitutionally necessary and would probably be out of step with contemporary taste in such matters. It would be a treat for constitutionalists, nevertheless, to see this long-neglected piece of constitutional machinery fired up once again!

157 On one view, London's input was in fact the cause of its embarrassment : see above, $\mathrm{n} 3$.

${ }^{158}$ See above, fnn 62, 72.
} 
for someone favoured by a political leader. The independence of the process for awarding the Order of Australia is one of its most attractive features and a vast improvement on the old Imperial awards, but here is a point at which the perception, at least, is not in line with this aspiration - possibly even the reality in rare cases. This perception is not dispelled when we find that high-ranking public servants are many jurisdictions' preferred appointees to the Council.

No easy solution exists. One simple, although not necessarily effective expedient would be simply to clarify the issue of whom these appointees represent in the Order's constitution : a new sub-section could state that they are not representatives of their governments nor even subject to their instructions but represent instead the whole polity from which they are taken. ${ }^{159}$ However, it may well be that better representatives of the States and territories can be found. Could each jurisdiction be required to nominate someone by vote in both Houses of its legislature? Some members of University councils were once elected in that way, occasionally legislation such as s 21 (1) (f) of the Tobacco Act 1987 (Vic.) still provides for such a procedure, and surely one person in each State and territory could be found who is capable of receiving sufficient cross-party support. Such a process would promote the selection of people who are independent and not reliant upon a government for their re-appointment, whether in return for services rendered on the Council or otherwise. If applications were called for, a further step would be taken to promote public involvement in the Order and the transparency of its decision-making. Consideration could also be given to ensuring that there is always one member of the Council who is of Aboriginal or Torres Strait Islander origin, perhaps included within the Prime Minister's quota of eight places on the Council.

The Order of Australia will celebrate its golden anniversary in 2025 - a jubilee which might prompt its administrators to sponsor the missing general history of it and an enterprising historian to take up that challenge by producing a history comparable to Dr McCreery's general history of the Order of Canada. ${ }^{160}$ It can certainly be said, however, that the Order of Australia has proved its worth over its nearly fifty years of existence and the principles on which it is founded are generally sound. Nevertheless there is always room for improvement. The ideas of giving the Order a statutory basis, stating that the governmentally appointed Council members are not representatives of their governments

\footnotetext{
${ }^{159}$ Cf. University of Tasmania Act 1992 (Tas.) s 8 (3) : 'A member of the Council is responsible and accountable to the Council rather than to any constituent body by which he or she was appointed or elected'.

${ }^{160}$ McCreery, above $\mathrm{n} 55$.
} 
but of their communities and having State Parliaments elect the States' representatives on the Council of the Order are desirable improvements that are wholly within the Order's existing principles. 